\title{
Analisis Genetik Objektif Afektif atas Alquran dan Terjemahnya dalam Bahasa Jawa Banyumasan
}

\author{
Siswoyo Aris Munandar', Laelatul Barokah ${ }^{2}$, Elia Malikhaturrahmah ${ }^{3}$ \\ ${ }^{1}$ Sekolah Tinggi Filsafat Islam (STFI) Sadra Jakarta \\ 2Universitas Islam Negeri (UIN) Sunan Kalijaga Yogyakarta \\ ${ }^{3}$ Universitas Islam Negeri (UIN) Sunan Kalijaga Yogyakarta \\ Corresponding E-mail: siswoyoaris31@gmail.com
}

\begin{abstract}
The focus of the study conducted by the researcher this time is on the translator section, the product and the public's response to the translation. As for the translator, the writer terms it with the genetic aspect, the researcher's product is the objective aspect, while the response of the research community is termed the affective aspect. So that the problem formulations built by the researcher include (1) How is the method of translating the Qur'an and its translation: Javanese Banyumasan?, (2) What is the quality of the translation of the Al-Qur'an and its translation: Javanese Banyumasan ?, (3) How Banyumas community response with the presence of the Qur'an and its translation: Javanese Banyumasan ?. The results of this study are; First, related to the method, this translation is a type of tafsiriah translation or communicative translation. The Banyumas language, which basically does not recognize upload-upload or karmic system, is feared that it will damage the sacred and transcendental nuances of the Qur'an, therefore the translator uses a compromise decision, namely the Banyumas language which adapts ethics. Second, related to the quality of the translation, this translation falls into the fair category. The trend used in this translation is domestication. Third, regarding the public's response to this translation, many have chosen an "easy" level of readability, meaning that the level of acceptance in the community is also "accepted".
\end{abstract}

Keywords: Translation, Genetic, Objective, Affective.

Abstrak: Fokus kajian yang dilakukan peneliti kali ini adalah pada bagian penerjemah, produk dan respons masyarakat terhadap terjemahan tersebut. Adapun bagian penerjemah penulis istilahkan dengan aspek genetik, pada produk peneliti istilahkan dengan aspek objektif sedangkan respons masyarakat peneliti diistilahkan dengan aspek afektif. Sehingga rumusan masalah yang dibangun oleh peneliti meliputi (1) Bagaimana metode penerjemahan Alquran dan Terjemahnya dalam Bahasa Jawa Banyumasan?, (2) Bagaimana kualitas terjemahan Alquran dan Terjemahnya dalam Bahasa Jawa Banyumasan?, (3) Bagaimana respons masyarakat Banyumas dengan hadirnya Alquran dan Terjemahnya dalam Bahasa Jawa Banyumasan?. Hasil penelitian ini berupa; Pertama, terkait dengan metodenya terjemahan ini merupakan jenis terjemahan tafsiriah atau terjemahan komunikatif. Bahasa Banyumas yang pada dasarnya tidak mengenal unggah-ungguh atau tata karma ini dikhawatirkan akan merusak nuansa suci dan transendental pada Alquran oleh karena itu penerjemah menggunakan keputusan kompromistis yaitu bahasa Banyumas yang mengadaptasi etika. Kedua, terkait dengan kualitas terjemahannya, terjemahan ini masuk dalam kategori wajar. Adapun kecenderungan yang dipakai dalam terjemahan ini adalah domestication. Ketiga, terkait dengan respons masyarakat terhadap terjemahan ini, banyak yang memilih tingkat keterbacaan "mudah" itu artinya tingkat penerimaannya di masyarakat juga "diterima".

Kata kunci: Terjemahan, Genetik, Objektif, Afektif. 


\section{Pendahuluan}

Alquran merupakan firman Allah yang berbahasa Arab, ${ }^{1}$ yang seluruh umat muslim meyakininya sebagai petunjuk bagi manusia dan penjelas atas segala sesuatu. ${ }^{2}$ Seiring berkembangnya waktu, Islam telah menyebar di berbagai wilayah, dengan kebudayaan dan peradaban yang berbeda (tidak sesuai ketika Alquran turun) untuk itu menambah kesulitan bagi orang muslim memahami isi kandungan dari Alquran. ${ }^{3}$ Kebutuhan umat Islam akan kandungan makna dari Alquran menuntut kemunculan naskah Alquran yang dilengkapi dengan bahasa non Arab (termasuk Indonesia) dalam bentuk yang disebut terjemahan ${ }^{4}$ agar dengan mudah dapat dipahami oleh mereka yang tidak menguasai bahasa Arab. ${ }^{5}$

Penerjemahan Alquran bukanlah hal yang baru. Ia telah dilakukan sejak abad ke-2 M, di mana Alquran diterjemahkan ke dalam bahasa latin oleh Robert of Ketton. Hingga saat ini Alquran telah di terjemahkan ke dalam berbagai bahasa dunia ${ }^{6}$ seperti bahasa Persia, Turki, Urdu, India, Jepang, Inggris, Prancis dan Spanyol, Mandarin, Indonesia hingga beberapa bahasa negara-negara di Afrika. Ini dilakukan berangkat dari berbagai kebutuhan masyarakat setempat. ${ }^{7}$ Melihat kebutuhan-kebutuhan yang semakin

${ }^{1}$ Q.S az-Zukhruf (43) : 3 .

2 Istianah, "Dinamika Penerjemahan Al-Qur'an: Polemik Karya Terjemahan HB Jassin dan Terjemah Tafsiriyah an Muhammad Thalib”, Maghza, Vol. 1, No.1, (2016), 41.

${ }^{3}$ Mohamad Yahya, "Analisis Genetik Objektif atas Al-Qur'an al-Karīm: Terjemah Tafsiriyah karya M. Thalib”, Thesis, Program Pascasarjana UIN Sunan Kalijaga, Yogyakarta, 1.

${ }^{4}$ Kata terjemah merupakan adopsi dari bahasa Arab yaitu ترجمه yang mengandung arti: menjelaskan dengan bahasa lain, atau memindahkan makna dari satu bahasa ke bahasa lain. lihat M. Tata Taufik M, Terjemah Dari Teori Ke Praktek (Kuningan: al-Ikhlash, 2001), 27. Sedangkan dalam Kamus Bahasa Indonesia, makna terjemah adalah menyalin atau memindahkan suatu bahasa ke bahasa lain. Menerjemahkan adalah mengalihbahasakan, mengalihsuarakan, mengartikan, menafsirkan dan menginterpretasikan. Lihat, Kamus Bahasa Indonesia. Antara terjemah dan tafsir sebenarnya hampir sama yaitu sama-sama mengalih bahasakan untuk menjelaskan suatu makna atau kata. Menurut Nashruddin Baidan tafsir jangkauanya lebih luas daripada terjemah. Jika terjemah hanya alih bahasa (artinya informasi yang diberikanya hanya sebatas ayat yang diterjemahkan itu saja tanpa memberikan yang rinci). Sebaliknya Tafsir berusaha memberikan penjelasan yang memadai tentang ayat yang dijelaskan, sehingga tergambar dalam benak pembaca dan pendengar kedalaman dan keluasan makna yang dikandung oleh ayat yang ditafsirkan tersebut. lihat Nashruddin Baidan, Wawasan Baru Ilmu Tafsir (Yogyakarta: Pustaka Pelajar, 2016), 70.

${ }_{5}^{5}$ Mohamad Yahya, "Analisis Genetik Objektif atas Al-Quran Al-karīm", 2.

${ }^{6}$ Bahasa berperan sangat penting dalam kehidupan bermasyarakat. Tanpa bahasa, masyarakat tak mungkin bisa berinteraksi, dan sebaliknya tanpa masyarakat, bahasa tak akan pernah ada. Lihat Hatmiati dan Husin, ”Budaya Dalam Penerjemahan Bahasa”, Jurnal al-Mi'yar, Vol. 1, No. 2, $2018,51$.

7 Anisah Indriati, “Kajian Terjemah Al-Qur'an: Studi Terjemah Al-Qur'an Basa Jawi Assalam karya Abu Taufiq S", Maghza, Vol. 1, No. 1, 2. Abdullah Saeed mengatakan dalam buku Pengantar Studi Al-Qur'an bahwa sekitar abad ke $12 \mathrm{M}$ praktek terjemahan Alquran yang cukup penting mulai dilakukan oleh kalangan non muslim, dan hingga akhir-akhir ini secara relative muncul terjemahan yang bernuansa polemik. Selengkapnya lihat Abdullah Saeed, Pengantar Studi Al-Qur'an, terj. Shulkhah dan Sahiron Syamsuddin, (Yogyakarta: Baitul Hikmah, 2016), 206. 
mendesak dan kompleks akan pemahaman ajaran keagamaan yang bersumber dari Alquran oleh masyarakat muslim di penjuru dunia, maka upaya penerjemahan ini tidak hanya berhenti pada bahasa nasional Kebangsaan saja. ${ }^{8}$

Di Indonesia, yang notabene terdiri dari berbagai suku dan ras, juga telah lahir berbagai karya terjemah Alquran. ${ }^{9}$ Sejak awal abad kedua puluh tidak kurang dari 20 karya terjemahan ditemukan dalam bahasa Indonesia dan berbagai bahasa daerah. Terjemahan yang populer dalam bahasa Indonesia antara lain terjemahan Mahmud Yunus, Al-Furqon karya A. Hasan, Al-Bayan karya T.M Hasbi Ash-Shiddieqy, dan yang terbaru Alquran dan Maknanya karya M. Quraish Shihab. ${ }^{10}$ Adapun yang penulis ketahui dalam bahasa daerah yaitu terjemahan Alquran bahasa Aceh, terjemahan Alquran bahasa Madura, ${ }^{11}$ terjemahan Alquran bahasa Melayu, terjemahan Alquran bahasa Mandhar, terjemahan Alquran bahasa Sasak dan lain-lain. Karya-karya tersebut tentu berbeda antara satu dengan lainnya.

Dalam hal ini kiranya yang perlu diketahui dalam sebuah terjemahan adalah setiap bahasa tidak mungkin dapat disamakan dengan bahasa lain dari segala aspeknya baik sifat, susunan, bentuk metafora, kosakata, kata kerja dan lainnya. Ketidaksamaan antara bahasa-bahasa manusia menjadi problem utama dalam proses penerjemahan. Muchlis Hanafi menyebutkan, problematika terjemahan terletak pada dua hal prinsip. Pertama, ketidaksesuaian antara bahasa-bahasa, dalam hal ini bahasa sumber dengan bahasa sasaran, dari berbagai segi. Kedua, kesenjangan antara penerjemah dan penulis, penulis teks dan produsennya. ${ }^{12}$ Berkaitan dengan itu, sekitar tahun 2011, tim dosen IAIN Purwokerto membuat terjemahan Alquran dalam bahasa Jawa Banyumasan. ${ }^{13}$

\footnotetext{
${ }^{8}$ Anisah Indriati, “Kajian Terjemah Al-Qur'an”, 2.

${ }^{9}$ Ibid.

${ }^{10}$ Muchlis M. Hanafi, "Problematika Terjemahan Al-Qur'an: Studi pada Beberapa penerbitan AlQur'an dan Kasus Kontemporer”, Suhuf, Vo. 4, No. 2, 2011, 178.

${ }^{11}$ Contohnya bisa melihat tafsir Jalalain dan bahasa Madura. Lihat Ahmad Zaidamil Kamil, "Tafsir Al-Jalalain dan Bahasa Madura: Lokalitas Kitab terjemahan Tafsir al-Jalalain bi al-Lugah alMadiriyyah Karya Abdul Majid Tamim (1919-2000)”, Jurnal Suhuf, Vol. 13, No. 1, (2020): 27-53 DOI: https//doi.org/10.22548/shf.vi3ii 533, dan lihat juga, Ahmad Zaidamil dan Fawaidur Ramadhani, "Tafsir al-Qur'an bahasa Madura: Kajian atas Tafsir Alqur'anul Karim Nurul Huda Karya Mudhar Tamim", Jurnal Suhuf, Vol. 12, No. 2 (2019): 201-225 DOI:https//doi.org/10.22548/shf.visis.475

${ }^{12}$ Muchlis M. Hanafi, "Problematika Terjemahan Al-Qur'an", 170.

${ }^{13}$ Tanto Sukardi menyebutkan bahwa istilah Banyumas pada masa kolonial secara administratif mempunyai tiga pengertian. Pertama, menunjuk pada suatu wilayah yang berkedudukan sebagai pusat administrative district (Distrik Banyumas) yang terletak di tepi sebelah Selatan sungai Serayu. Walapun hanya berstatus sebagai pusat pemerintahan distrik, namun secara historis pernah memiliki kedudukan yang penting. Hal ini mengingatkan pada zaman kerajaan Islam, baik Demak, Pajang maupun Mataram dan Surakarta, kota Banyumas pernah memiliki kedudukan sebagai pusat pemerintahan daerah
} 
Terjemahan ini dilakukan dengan maksud pertama untuk memudahkan masyarakat sekitar dalam memahami Alquran. Kedua, penerjemahan ini dilakukan dengan upaya untuk lebih mendekatkan Alquran ke komunitas abangan. ${ }^{14}$ Golongan ini yang menurut Ahmad Tohari $^{15}$ jumlahnya lebih besar dibandingkan pengikut NU maupun

mancanegara kilen (barat). Kedua, untuk menyebut wilayah inti Banyumas yang disebut Lembah Serayu yang bersetatus sebagai regentschap atau kabupaten (Kabupaten Banyumas) dengan pusat pemerintahanya di kota Banyumas. Status Banyumas sebagai kabupaten seperti itu masih dipertahankan sampai sekarang, tetapi pusat pemerintahanya berada di kota Purwokerto. Ketiga, istilah Banyumas disebutkan untuk menyebut gabungan wilayah yang lebih luas, yaitu Banyumas dan sekitarnya yang pada masa kolonial tergabung dalam ikatan wilayah administrative residentie atau karisidenan (Karisidenan Banyumas), yang terdiri dari lima kabupaten, yaitu Banjarnegara, Purbalingga, Cilacap, Purwokerto dan Banyumas sendiri dengan pusat pemerintahanya di kota Banyumas. Lazimnya istilah yang terakhir ini dikaitkan juga dengan kesamaan identitas budaya lokal yang dikenal dengan istilah budaya Banyumasan. Lihat, Tanto Sukardi, Tanam Paksa di Banyumas; Kajian Mengenai Sistem, Pelaksanaan dan Dampak Sosial Ekonomi (Yogyakarta: Pustaka Pelajar, 2014), 1-2. Berbicara mengenai identitas, Teguh Trianton menyebutkan dalam buku Identitas Wong Banyumas yang mengutip dari Herusatoto bahwa candrajiwa wong Banyumas dapat dikenal dari lageyan atau tingkah laku dan kebiasaan hidup sehari-hari. Lageyan wong Banyumas adalah segala tingkah laku dalam menghadapi berbagai persoalan kehidupan sehari-hari yang dipengaruhi kearifan lokal produk budaya nenek moyang. Ciri-ciri Lageyan wong Banyumas adalah (1) cowag yaitu berbicara dengan suara keras; (2) mbloak yaitu gaya bicara serius, cablaka, dan humoris yaitu apa yang diomongkan seperti nyata tapi belum tentu dilaksanakan; (3) dablongan atau ndablong, yaitu seenaknya sendiri memberi kritikan atau dengan berkelakar; (4) ajiban, ungkapkan spontan saat mendapat kenikmatan; (5) ndobos, yaitu berebut dalam memberikan gagasan tapi pada ujungnya omong kosong belaka; (6) mbanyol, suka bertingkah konyol atau lucu dan saling menyindir; (7) kluyuran atau ngluyur, yaitu melonceng atau jalan-jalan ke luar rumah; dan (8) ndopok, yaitu berbicara ngudarasai atau mengeluarkan uneg-uneg dan pendapat lainya. Diungkapkan juga oleh Priyadi, bahwa pada kisah wayang gaya Banyumas, tokoh Bawor merupakan anak tertua dari Ki Semar dan Ki Lurah Badrayana. ia tercipta dari bayangannya sendiri, sehingga secara fisik postur tubuh Bawor mirip dengan semar. Postur tubuh Bawor mirip dengan Semar yang nyaris bulat (tambun) dan besar. Tampilan ini menjadi ciri yang menggambarkan watak Bawor yang memiliki sifat terbuka (ceplas-ceplos), jujur, sportif, dan bertanggungjawab, watak Bawor merepresentasikan watak wong Banyumas yang; (1) sabar lan nrima; (2) berjiwa kesatria; (3) cancudan; dan (4) cablaka (terbuka). Selengkapnya lihat Teguh Trianton Identitas Wong Banyumas (Yogyakarta: Graha Ilmu, 2013), 16.

${ }^{14}$ Clifford Greetz menuliskan dalam buku Agama Jawa tentang skema konsepsi pembagian masyarakat Jawa berdasarkan penelitian lapangan di Majokuto adalah tiga tipologi budayawi utama, yakni; abangan, santri, dan priyayi. Tiga varian tersebut secara ringkas dideskripsikan sebagai berikut: Abangan yang mewakili sikap menitikberatkan segi-segi animisme sinkretisme Jawa yang menyeluruh, dan secara luas berhubungan dengan unsur-unsur petani di antara penduduk; Santri yang mewakili sikap menitikberatkan pada segi-segi Islam dalam sinkretisme tersebut, pada umumnya berhubungan dengan unsur pedagang (maupun juga dengan unsur-unsur tertentu di antara para petani); dan Priyayi yang sikapnya menitikberatkan pada segi-segi Hindu dan berhubungan dengan unsur-unsur birokrasi.Istilah abangan oleh Clifford Geertz diterapkan pada kebudayaan orang desa, yaitu para petani yang kurang terpengaruh oleh pihak luar dibandingkan dengan golongan-golongan lain di antara penduduk. Adapun istilah santri diterapkan pada kebudayaan muslimin yang memegang peraturan dengan keras dan biasanya tinggal bersama di kota dalam perkampungan dekat sebuah masjid yang terdiri dari para pedagang di daerah-daerah yang lebih bersifat kota. Istilah priyayi diterapkannya pada kebudayaan kelas-kelas tertinggi yang pada umumnya merupakan golongan bangsawan berpangkat tinggi atau rendah. Selengkapnya lihat Cifford Greetz, Agama Jawa; Abangan, Santri, Priyayi dalam Kebudayaan Jawa, terj. Aswab Mahasin dan Bur Rasuanto (Depok: Pustaka Jaya, 2013), xxx.

15 Ahmad Tohari adalah Budayawan asal Banyumas yang lahirkan di Desa Tinggarjaya, Kecamatan Jatilawang, Banyumas, pada tanggal 13 Juni 1948. Beliau merupakan editor Alquran Terjemah Bahasa Banyumas. Beliau memiliki beberapa karya salah satunya yaitu serial Trilogi: Ronggeng Dukuh Paruk-Lintang Kemukus Dini Hari-Jantera Bianglala. Lihat Ahmad Tohari Bekisar Merah (Jakarta: Gramedia, 2013), 359. 
Muhammadiyah. Ketiga, untuk melestarikan bahasa Banyumas yang disinyalir mulai terancam punah. ${ }^{16}$ Setiap bahasa memiliki akar serta lingkungan kultural yang spesifik. ${ }^{17}$ Maka karya tulis apapun, terlebih lagi Alquran ketika diterjemahkan sudah pasti mengalami perubahan makna, baik perubahan yang bersifat pengembangan maupun penyusutan. ${ }^{18}$

Masyarakat Banyumas memiliki keunikan-keunikan tersendiri dalam berbicara. Salah satunya dari pengungkapan kata saya (Indonesia) dalam bahasa Jawa menjadi aku kemudian dalam bahasa Banyumas menjadi Inyong. Bisa dilihat dalam menerjemahkan Q.S. Al-Baqarah (2): 139:

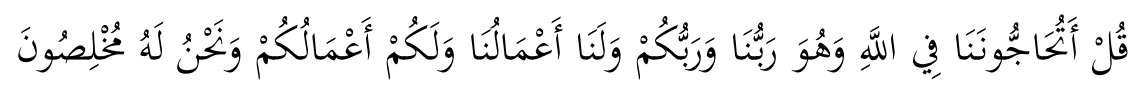

Terjemahan Banyumas: Dawuha (Muhammad), "apa ko arep dhebadan karo inyong ngenani gusti Allah. Mangka penjenengané pangéranku lan pangéranmu kabéh. Nggo inyong kabéh ngamalngamalku, lan nggo ko kabéh ngamal-ngamalmu, lan mung maring panjenengané inyong kabéh kanthi tulus oléhé kemawula. ${ }^{19}$

Terjemahan Kemenag: Katakanlah: "Apakah kamu memperdebatkan dengan kami tentang Allah, padahal Dia adalah Tuhan kami dan Tuhan kamu; bagi kami amalan kami, bagi kamu amalan kamu dan hanya kepada-Nya kami mengikhlaskan hati.

Kata itu dalam bahasa jawa iku dalam bahasa Banyumas menjadi kuwe. Sebagai contoh bisa dilihat dalam Q.S. al-Baqarah(2): 143:

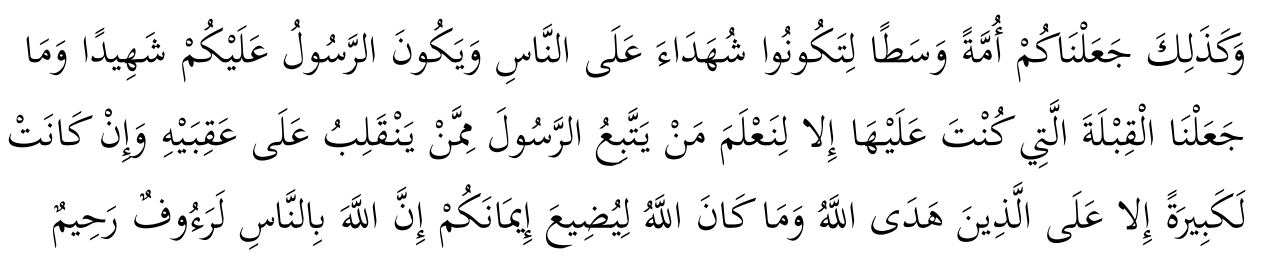

Terjemahan Banyumas: Lan mengkana uga ingsun wes ndadékna ko kabéh (wong Islam) "umat sing tengah-tengah” supaya ko kabéh dadi seksi ingatasé (temindaké) manungsa lan supaya Rasul (Muhammad)

16 Hakiem syukrie, "Qur'an Terjemah Basa Ngapak" dalam https://hakiemsyukrie.wordpress.com/2016/05/13/quran-terjemah-basa-ngapak/ (diakses pada tanggal 13 Mei 2016).

${ }^{17}$ M. Pudail, “Terjemah Al-Qur'an dalam Bahasa Mandar”, Skripsi, Fakultas Ushulludin UIN Sunan Kalijaga, Yogyakarta, (2003), 1.

18 Komaruddin Hidayat, Memahami bahasa Agama; Sebuah Kajian Hermeunetika (Jakarta: Paramadina, 1996), 172. Dalam kajian terjemahan, orientasi penerjemah di kategorikan dalam dua hal, yaitu foreignization dan demostication. Foreignization adalah terjemahan yang penerjemahnya berusaha menghadirkan apa yang dimaksudkan oleh pengarang. Sedangkan demostication adalah terjemah yang penerjemahnya mengadaptasi hasil terjemahan dengan budaya pembaca. Mohamad Yahya, "Analisis Genetik Objektif atas Al-Quran al-Karīm, 22.

19 Ahmad Tohari dkk, Al-Qur'an dan Terjemahnya: Bahasa Jawa Banyumasan. Cet. Ke-2 (Jakarta: Puslitbang Lektur dan Khazanah Keagamaan, 2016), 25. 
dadi saksi maring temindakmu kabéh. Ingsun ora ndadékna kiblat seng (gemiyén) sliramu padha (ngiblat) maring kaé kejaba supayané ingsun priksa sapa seng ngetutna Rasul lan sapa seng mbalék maring mburi. Temen (pindahé kiblat)kuwé abot banget, kejaba tumprap wong sing wis déparingi pituduh déning Gusti Allah. Lan Gusti Allah ora bakal siyasiya maring percayamu kabéh. Temen, Gusti Allah Mahaasih, Mahawelas maring manungsa. ${ }^{20}$

Terjemahan Kemenag: Dan demikian (pula) Kami telah menjadikan kamu (umat Islam), umat yang adil dan pilihan agar kamu menjadi saksi atas (perbuatan) manusia dan agar Rasul (Muhammad) menjadi saksi atas (perbuatan) kamu. Dan Kami tidak menetapkan kiblat yang menjadi kiblatmu (sekarang) melainkan agar Kami mengetahui (supaya nyata) siapa yang mengikuti Rasul dan siapa yang membelot. Dan sungguh (pemindahan kiblat) itu terasa amat berat, kecuali bagi orang-orang yang telah diberi petunjuk oleh Allah; dan Allah tidak akan menyianyiakan imanmu. Sesungguhnya Allah Maha Pengasih lagi Maha Penyayang kepada manusia.

Demikian tadi dua contoh kata yang menggambarkan ciri dari bahasa Banyumas yang terdapat dalam Alquran dan Terjemahnya: Bahasa Jawa Banyumasan, bahasa yang hanya bisa ditemukan di daerah karisidenan Banyumas. Banyumas adalah sebuah entitas sosial politik sekaligus entitas budaya yang memiliki bahasa daerah yang sering disebut dialek ngapak ${ }^{21}$ sebagai identitasnya. Masyarakat di wilayah Banyumas menggunakan dialek ngapak dalam kehidupan untuk berkomunikasi sehari-hari baik itu dalam lingkungan keluarga, sekolah ataupun masyarakat. Dalam wilayah Banyumas dialek ngapak bisa disebut Bahasa Jawa dialek Banyumas. ${ }^{22}$ Minusnya dari Bahasa Jawa dialek Banyumas adalah tidak memiliki eksistensi kebahasaan layaknya bahasa Jawa dan Sunda.

Bukti sejarah menyebutkan bahwa pada masa lampau, Solo dan Yogya adalah pusat kerajaan besar kesultanan Mangku - negara dan kesultanan Yogyakarta Hadiningrat. Dua bekas Kerajaan ini hidup pujangga-pujangga besar yang melahirkan

\footnotetext{
${ }^{20}$ Ibid., 26.

${ }^{21}$ Disebut Ngapak karena pengucapan vocal a dan o, konsonan b, d, k, g, h, y, k, l, dan w, sangat mantap (luged), tegas, lugas, tidak mengambang (ampang) atau setengah-setengah, seperti yang diajarkan disekolah formal yang disebut sebagai bahasa Jawa baku. Bahasa Jawa baku itu sendiri sesungguhnya merupakan perkembangan terakhir dari tahap sejarah bahasa Jawa yang terbentuk pada zaman Pujangga Baru abad ke-18. Sedangkan bahasa ngapak adalah bahasa Jawa dari tahap awal yang disebut tahap bahasa Jawadwipa atau bahasa dari orang yang tinggal di pulau Jawa, yang konon adalah bahasa Jawa murni (pure Javaness Language). Lihat Budiono Herusatoto, Seri Satu Abad Kebangkitan Nasional Banyumas: Sejarah, Budaya, Bahasa, dan Watak (Yogyakarta: LKiS, 2008), 6-7.

${ }^{22}$ Dwiana Anugrahita dan Sudartomo Macaryus, "Identitas Kebanyumasan dalam Penggunaan Bahasa di Ruang Publik", Vol. 1, No. 2, (2015), 60.
} 
karya-karya sastra Jawa yang adiluhung. Dari faktor inilah, dialek Solo dan Yogyakarta mendapatkan prestasinya, dan tidak mengherankan, serta cukup beralasan bila kemudian dialek ini dijadikan sebagai bahasa standar di dalam kebijakan pengembangan dan pembinaan bahasa Jawa. ${ }^{23}$ Bila dilihat dari kedua faktor ini, dialek-dialek bahasa Jawa lain tidak menguntungkan dan akhirnya terpinggirkan. ${ }^{24} \mathrm{Hal}$ ini pula yang terjadi pada bahasa Jawa Banyumasan. ${ }^{25}$

Wilayah Banyumas secara kebahasaan berbatasan dengan wilayah tutur bahasa Jawa Yogyakarta di sebelah Timur dan Barat kota Tasikmalaya. Kondisi ini menyebabkan bahasa Jawa Jawa Banyumasan di satu sisi menyerap unsur-unsur bahasa Jawa Standar, tetapi di sisi lain tetap menyerap bahasa Sunda. Bahasa Jawa Banyumasan merupakan salah satu identitas budaya yang hidup di perbatasan budaya Jawa dan Sunda. ${ }^{26}$

Berangkat dari beberapa problem di atas kemudian penulis merasa perlu mengkaji Alquran terjemahan bahasa Banyumas. Dalam satu sisi sebagai pelestarian budaya, khususnya bahasa Jawa Banyumasan dan di sisi lain menunjukkan bahwa bahasa Jawa Banyumasan mampu ekses meskipun tidak menjadi bahasa standar di Jawa. Adapun dalam penelitian ini penulis ingin mengungkapkan bagaimana karakteristik Alquran dan Terjemahnya: Bahasa Jawa Banyumasan dan respons masyarakat atas hadirnya terjemahan tersebut.

23 Jawa Tengah, Yogyakarta dan Jawa Timur merupakan daerah yang memakai bahasa Jawa, sekaligus menjadi kota perdangangan dan kota pendidikan akan selalu menjadi tujuan orang diluar daerah untuk datang dan menetap dalam waktu sebentar atau lama bahkan tidak sedikit yang tinggal selamanya. Dengan atau tanpa kesadaran mereka pasti akan berusaha bisa berbahasa Jawa untuk keperluan komunikasi sehari-hari. Selama mereka tinggal di Jawa, mereka akan menjadi pendukung atau pemakai bahasa Jawa, artinya mereka juga terlibat dalam proses pemeliharaan bahasa Jawa dalam kurun waktu tertentu. Lihat, Yulia Esti Kartini, "Fakta Sosial Bahasa Jawa dan Eksistensinya", Vol. 31, No. 1, (2009), 7.

${ }^{24}$ I Dewa Putu Wijana, "Pemertahanan Dialek Banyumas Terhadap Dominasi Dialek SoloYogya”, Humaniora, Vol. 17, No. 2, (2005), 157.

${ }_{25}$ Dilihat dalam tuturan sejarah disebutkan bahwa Banyumas merupakan daerah mancanagari (sebuah daerah yang jauh dari pusat kekuasaan keraton). Dalam kondisinya yang seperti ini, Banyumas sangat sedikit dipengaruhi budaya keraton. Hal ini juga digambarkan oleh peribahasa Jawa sendiri yang menunjukan pada karakter Wong Banyumasan yaitu 'Adoh Ratu Cedhak Watu' yang artinya (Banyumas itu) jauh dari raja dan hanya dekat dengan batu. Lihat Munawir, "Al-Qur'an dan Terjemahnya Bahasa Jawa Banyumasan (Telaah Karakteristik dan Konsistensi Terjemahan Juz 30)”, ibda, Vol. 17, No. 2, 2019, 264-265. Lihat juga Munawir, “Al-Qur'an dan Terjemahnya Bahasa Jawa Banyumasan (Telaah Karaktersitik dan Konsistensi Terjemahan), dalam Tafsir Al-Qur'an di Nusantara, ed. Ahmad Baidowi, Yogyakarta: Lembaga Ladang Kata, 2020, 303.

${ }^{26}$ Retno Khoirul Mar'ah dan Umi Hartati, "Penggunaan Bahasa Jawa Dialek Banyumas dalam Seni Begalan di Cilacap”, Caraka, Vol. 2, No. 1, (2015). 121. 


\section{Metode Menerjemahkan Alquran dan Terjemahannya: Bahasa Jawa Banyumasan}

\section{Latar Belakang Penerjemahan Alquran Bahasa Banyumas}

Alquran dan Terjemahannya; Bahasa Jawa Banyumasan disusun sejak tahun

2011. Penyusunan ini berlangsung sekitar kurang lebih 2,5 tahun oleh tim penerjemah yang terdiri dari 10 orang. Mereka adalah Kh Ahmad Tohari, ${ }^{27}$ Dr. A Luthfi Hamidi, M.Ag, ${ }^{28}$ KH. Drs. Khariri Shofa, M.Ag, KH Thoha al-Hafidz, ${ }^{29}$ Dr. Suprianto, Lc., M.S.I, ${ }^{30}$ Dr. Sofwan Mabrur, Drs. Attabik, M.Ag, Nurma Ali Ridwan, M.Ag, Muhyiddin Dawud L.M.Pd.I, dan Ahmad Muttaqin, M.Si. Nama-nama tersebut mewakili tiga kalangan meliputi ulama, budayawan, dan akademisi.

Keberadaan Alquran dan Terjemahannya; Bahasa Jawa Banyumasan melengkapi terjemahan-terjemahan lain yang sudah ada seperti terjemahan bahasa Madhura, terjemah bahasa Aceh, terjemah bahasa Mandhar, dan lain-lain. Terjemahan ini

${ }^{27}$ Ahmad Tohari, lahir di Tinggarjaya, Jatilawang, Banyumas, Jawa Tengah, pada tanggal 13 Juni 1948. Ia menamatkan pendidikannya di Sekolah Rakyat Tinggarjaya II (1954-1960), SMP Negeri Purwokerto (1960-1963) SMA Negeri II di Purwokerto (1963-1966). Setelah itu ia menimba ilmu di Fakultas Ilmu Kedokteran Ibnu Khaldun, Jakarta (1967-1970), Fakultas Ekonomi Universitas Sudirman, Purwokerto (1974-1975), dan Fakultas Sosial Politik Universitas Sudirman (1975-1976). Tohari merupakan seorang penulis, budayawan dan sastrawan banyumasan. Ia pernah bekerja sebagai wartawan tahun 1870-1979, Redaktur Harian Merdeka di Jakarta tahun 1979-1982, Redaktur majalah keluarga di Jakarta tahun 1983-1985, redaktur majalah Amanah di Jakarta tahun 1986-1993, penulis lepas harian suara merdeka, republika, kompas, jawa pos tempo, pemimpin redaksi majalah banyumasan Ancas di purwokerto tahun 2010-sekarang, penyunting kamus terjemahan Bahasa Banyumas, penyunting utama teks Terjemahan Al-Qur'an Bahasa Banyumas. Dalam karier kepengarangannya, penulis yang berlatar kehidupan pesantren ini telah melahirkan novel dan kumpulan cerita pendek. Beberapa karyanya adalah Di Kaki Bukit Cibalak, 1979, K U B A H, 1980 (juga diterjemahkan ke Bahasa Spanyol), Ronggeng Dukuh Paruk, 1981 (telah diterjemahkan ke Bahasa Jepang, Cina, Jerman, Inggris, Belanda, Banyumas), Lintang Kemukus Dini Hari, 1984 (telah diterjemahkan ke Bahasa Jepang, Cina, Jerman, Inggris, Belanda, Banyumas), Jantera Bianglala, 1985 (telah diterjemahkan ke Bahasa Jepang, Cina, Jerman, Inggris, Belanda, Banyumas, Bekisar Merah, 1990 (juga terbit dalam Bahasa Inggris), Belantik, 1993 (diterjemahkan ke Bahasa Inggris), Lingkar Tanah Lingkar Air, 1991, Orang-orang Proyek, 2002. Perangai berpakaian yang sederhana mengingatkan pada seorang santri saleh yang mempunyai wawasan terbuka bisa menerima semua insan di dunia dari segala lapisan untuk hidup berdampingan secara damai sebagai sesama ciptaan Tuhan. Rendah hati, itulah sosok Ahmad Tohari, yang ternyata merupakan salah seorang kawan dekat Gus Dur. Lihat, Eka Dian Oktaviani, "Biografi Ahmad Tohari Kiprah dan Prestasi Sastrawan Banyumas Tahun 1970-2015", Skripsi, Fakultas Keguruan dan Ilmu Pendidikan Universitas Muhamadiyah Purwokerto, 24-35.

${ }^{28}$ Merupakan rektor IAIN Purwokerto.

${ }^{29}$ K.H Muhammad Thoha akrap dipanggil Abuya Thoha merupakan tim penerjemah dari kalangan pesantren. Ia lahir di desa Rejosari, Kecamatan Karangawen, Kabupaten Demak, Jawa Tengah pada tahun 1953. Ia merupakan pendiri Pondok Pesantren Ath-Thohiriyyah Purwokerto. Abuya Thoha pernah belajar di Pesantren Futuhiyyah Mranggen di Demak yang di asuh oleh KH. Muslih. Di Mranggen itulah ia belajar berbagai ilmu keagamaan di Madrasah Tsanawiyah dan Madrasah Aliyah. Selain di Mranggen Abuya juga pernah belajar di Kudus pada Mbah Arwani, Mbah Hisyam dan Mbah Wahab selama 1,5 tahun. Wawancara dengan salah satu santrinya dan lihat, http://www.thohiriyyah.com/abuya-kh-m-thohaalawy-al-hafidz/ (diakses pada tanggal 27 Agustus 2018 pukul 22.00 wib)

30 Merupakan wakil rektor III IAIN Purwokerto sekaligus merupakan koordinator tim penerjemahan Al-Qur'an bahasa Jawa Banyumasan. 
diterbitkan bekerjasama dengan Pusat Penelitian dan Pengembangan Lektur dan Khazanah Kementrian Agama. Diharapkan keberadaannya dapat dinikmati saudara muslim yang ada di lima kabupaten yang menggunakan bahasa Jawa Banyumasan. Kelima kabupaten ini adalah Banjarnegara, Purbalingga, Banyumas, Cilacap, dan Kebumen (Barlingmascakeb).

Latar belakang penyusunan terjemahan ini adalah sebagai upaya pengelolaan kekayaan bangsa dan pelestarian budaya daerah. Sudah menjadi keniscayaan Indonesia merupakan bangsa yang sangat majemuk. Tak kurang dari 700-an suku bangsa, 300 bahasa daerah yang masih hidup, enam agama yang tersebut dalam kontitusi, yaitu Islam, Kristen, Katolik, Hindu, Buddha, dan Konghucu serta ratusan kepercayaan lokal serta ribuan seni budaya daerah. ${ }^{31}$

Sebagai bangsa yang besar, Indonesia juga memiliki penduduk lebih dari 250 juta pada tahun 2015, mendiami lebih dari 17.000 pulau, dengan 500 suku, dan 300 bahasa lokal. Keragaman keagamaan, budaya, dan bahasa ini merupakan anugerah dan kekayaan bangsa Indonesia yang patut untuk dilestarikan. ${ }^{32}$ Dalam spektrum makro upaya penerjemahan Alquran ke dalam bahasa daerah diorientasikan kepada sejumlah tujuan. Beberapa tujuan tersebut adalah untuk memperkaya khazanah penerjemahan Alquran ke dalam bahasa daerah, memperluas dan mempermudah pemahaman Alquran bagi masyarakat pengguna bahasa daerah (bahasa ibu), dan mempermudah penerapan ajaran yang terkandung dalam Alquran. ${ }^{33}$

Ahmad Tohari menyampaikan latar belakang penerjemahan ini adalah sebagai upaya mendekatkan Alquran ke komunitas abangan. Golongan ini menurutnya jumlahnya lebih besar dibandingkan pengikut NU dan Muhammadiyah. Jumlah komunitas abangan sekitar 62 persen. Tohari juga menjelaskan bahwa ketika bahasa ibu membawa bahasa langit, maka akan lebih awet, abadi karena masyarakat Islam akan menjaga kalimatnya. Sudah saatnya kita melestarikan bahasa ibu yang demokratis tanpa strata. $^{34}$

\footnotetext{
${ }^{31}$ Ahmad Tohari, dkk, Al-Qur'an dan Terjemahnya: Bahasa Jawa Banyumasan, v.

${ }^{32}$ Ibid., vi.

33 http://hakimsyukrie.com/quran-terjemah-basa-ngapak/ (diakses pada tanggal 19 September

${ }^{34}$ https://www.dream.co.id/news/ini-alasan-Al-Qur'an-diterjemahkan-ke-bahasa-banyumasan-
} 2018) 151203u.html (diakses pada tanggal 19 September 2018) 


\section{Metode Penerjemahan}

Metode merupakan cara yang teratur dan terpikir baik-baik untuk mencapai sebuah maksud atau cara kerja yang bersistem untuk memudahkan pelaksanaan sebuah kegiatan guna mencapai tujuan yang ditentukan. Sedangkan penerjemahan adalah perbuatan menerjemahkan atau pengalihbahasaan. ${ }^{35}$ Dengan demikian metode penerjemahan Alquran adalah cara yang teratur untuk menerjemahkan Alquran.

Metode yang digunakan pada Alquran dan Terjemahannya: Bahasa Jawa Banyumasan adalah metode terjemahan tafsiriah bisa juga dikatakan sebagai terjemahan semantik serta terjemahan komunikatif. Kecenderungan terjemahan ini adalah ideologi domestication $^{36}$ yaitu ideologi yang berorientasi pada bahasa sasaran/teks sasaran. Menurut ideologi ini, penerjemahan yang benar dan berterima serta baik adalah yang sesuai dengan selera dan harapan reseptor. Ia menginginkan sebuah produk terjemahan yang sesuai dengan kebudayaan sendiri (reseptor bahasa sasaran/teks sasaran), bukan kebudayaan bahasa sumber/teks sumber (writer/author). ${ }^{37}$ Tujuan utama penerjemahan ini adalah untuk mendekatkan Alquran dengan komunitas abangan sehingga dapat membumi sesuai dengan yang diharapkan oleh penerima. ${ }^{38}$

Puslitbang Lektur dan Khazanah Keagamaan membagi proses penerjemahan Alquran dalam bahasa daerah ini menjadi 5 tahapan. Pertama, Mushaf Alquran diterjemahkan oleh Tim Penerjemah yaitu UIN IAIN STAIN. Tim Penerjemah ini terdiri dari ulama Alquran, akademisi dan pakar bahasa dan budaya daerah. Anggota tim ini harus memiliki kualifikasi: (1) Menguasai Bahasa Arab sebagai bahasa Alquran dengan baik (2) menguasai pengetahuan dasar ulumul Quran dan Tafsir (3) menguasai bahasa dan budaya daerah yang menjadi sasaran terjemah. Seluruhnya berjumlah sepuluh orang. Dalam proses penerjemahannya, Puslitbang LKK menyediakan buku Pedoman Penerjemahan Alquran ke dalam Bahasa Daerah, yang berisikan tata cara atau batasan-batasan sebagai rujukan dalam proses penerjemahan Alquran ke dalam bahasa daerah tersebut. Pedoman yang dimaksudkan ialah menyangkut beberapa hal, di antaranya, yaitu: ${ }^{39}$

\footnotetext{
${ }^{35}$ Dendy Sugono (red), Kamus Bahasa Indonesia, 1022

${ }^{36}$ Wawancara dengan Ahmad Tohari, pada tanggal 27 Agustus pukul 10.00 wib.

${ }^{37}$ Mohamad yahya, "Analisis Genetik-Objektif atas Al-Qur'an al-Karim”, 22

${ }^{38}$ Wawancara dengan Ahmad Tohari, pada tanggal 27 Agustus pukul 10.00 wib.

${ }^{39}$ Ahmad Thohari, dkk, Al-Qur'an dan Terjemahannya; Bahasa Jawa Banyumasan, II.
} 
a. Penggunaan Alquran dan Terjemahannya (dalam Bahasa Indonesia), terbitan Kementrian Agama tahun 2010 sebagai rujukan utama ke dalam bahasa daerah, termasuk penggunaan footnote yang ada di dalamnya.

b. Penggunaan teks ayat Alquran yang mengacu kepada Mushaf Alquran Standar Departemen Agama terbitan tahun 2009 dalam penerjemahan Alquran ke dalam bahasa daerah.

c. Penggunaan transliterasi Arab-Latin dalam penulisan Arab ke dalam Bahasa Indonesia.

Sementara langkah-langkah yang ditempuh oleh tim penerjemah yaitu dengan membagi Alquran menjadi tujuh bagian. Masing-masing tim mendapat kurang lebih empat juz-an. Setelah dibagi kemudian diterjemahkan ke dalam bahasa Jawa Banyumasan dengan mendasarkan pada terjemahan Alquran Kementrian Agama tahun 2010 dan disinkronkan dengan Alquran yang berbahasa Arab dan tafsir. Karakteristik bahasa Jawa Banyumasan berbeda dengan bahasa Jawa pada umumnya. Ketika terdapat makna yang tidak pas atau tidak sesuai dengan bahasa Jawa Banyumasan maka tim penerjemah akan merujuk langsung kepada Alquran atau tafsir untuk dicarikan padanan makna yang sesuai. Setelah tim penerjemah menyelesaikan bagianya, kemudian dikumpulkan menjadi satu. Kumpulan tersebut masih berupa draf kasar. Setelah terkumpul semua kemudian diselaraskan bahasanya sesuai kaidah bahasa Jawa Banyumasan oleh Ahmad Thohari dalam waktu kurang lebih sekitar 6 bulan. ${ }^{40}$

Kedua, tahap diskusi internal Tim. Pada tahap ini hasil terjemahan tim kecil dipresentasikan untuk dibahas, didiskusikan atau dilakukan inter-checking sehingga dihasilkan terjemahan yang siap untuk divalidasi. Ketiga, tahap validasi terhadap hasil Tim untuk melihat, mengecek dan mencermati hasil keseluruhan secara teliti, seksama, untuk menghindari kesalahan dalam penerjemahan baik dalam aspek tata bahasa, makna (arti), konteks budaya, serta ketepatan penulisannya. ${ }^{41}$

Validasi dilakukan sebanyak empat kali oleh validator yang terdiri dari ahli Alquran, ahli budaya dan bahasa daerah yang bersangkutan. Setelah dilakukan validasi secara keseluruhan yang dinilai valid secara subtantif maupun kebahasaannya kemudian diserahkan ke Puslitbang LKK. Keempat, tahap Pentashihan oleh Lajnah Pentashih

\footnotetext{
${ }^{40}$ Wawancara dengan Ahmad Muttaqin, di ruang IAIN Purwokerto pada tanggal 27 Agustus pukul 13.30 wib.

${ }^{41}$ Ibid.
} 
Mushaf Alquran (LPMA). Kelima, hasil pentashihan oleh LPMA dibuktikan dengan tanda tashih sebagai tanda bahwa terjemahan Alquran bahasa daerah tersebut dikategorikan sah (valid, benar atau legitimasi) untuk dimanfaatkan atau diedarkan ke masyarakat secara luas. ${ }^{42}$

Luthfi Hamidi, rektor IAIN Purwokerto menyebutkan bahwa persoalan prinsip sering kali menjadi sumber kegamangan para penerjemah, mengingat karakteristik bahasa Jawa Banyumasan yang pada dasarnya tidak mengenal unggah-ungguh atau tata krama. Karakteristik ini dikhawatirkan berpotensi menurunkan nuansa Alquran yang suci dan transendental. Dengan pertimbangan ini, penerjemah mengambil keputusan kompromistis, yaitu bahasa Jawa Banyumasan yang mengadaptasi etika. Dalam beberapa pokok penerjemahan menggunakan kosakata "etis" sebagai bentuk pemuliaan dan pembeda atas subjek dan objek tertentu. ${ }^{43}$ Seperti contoh pembedaan pengucapan kata kamu pada Allah, Nabi, dan Manusia, yaitu:

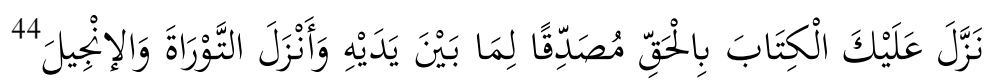

Terjemahan Banyumas: Panjenengané nurunaken kitab (Alquran) maring sliramu (Muhammad) sing isine bebener, mbenerna (kitabkitab) seurungé, lan nurunaken Taurat lan Injil. ${ }^{45}$

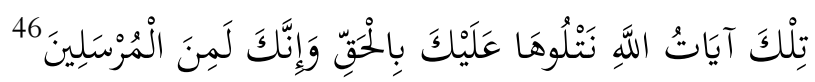

Terjemahan Banyumas: Nyata kuwé tandha-tandhane (kewasané) Gusti Allah, ingsun wacakna maring ko kabeh kanthi bener lan kiyambaké (Muhammad) kuwé nyata-nyata sewijine utusan (rasul) ${ }^{47}$

Terdapat tiga kendala utama dalam melakukan penerjemahan ini. Pertama, bahasa Jawa Banyumasan pada dasarnya memiliki karakteristik yang apa adanya (blakasuka) dan tidak mengenal kasta. Berbeda dengan Bahasa Jawa Solo dan Yogyakarta yang mengenal unggah-ungguh, bahasa Krama dan bahasa Madya. Hal ini ditakutkan menghilangkan kesakralan Alquran. Kedua, perkembangan bahasa Jawa Banyumasan tidak secepat bahasa Jawa pada umumnya. Sehingga banyak bahasa-bahasa yang ada dalam Alquran yang sulit diketahui. Seperti ketika mencari padanan kata homo pada Q.S. Al-Ankabut (29): 28:

\footnotetext{
${ }^{42}$ Ibid.

${ }^{43}$ Ahmad Tohari, dkk, Al-Qur'an dan Terjemahnya: Bahasa Jawa Banyumasan, xi-xii.

${ }^{44}$ Q.S. Ali-Imran (3): 3

${ }^{45}$ Ahmad Tohari, dkk, Al-Qur'an dan Terjemahnya: Bahasa Jawa Banyumasan, 49 ${ }^{46}$ Q.S. Al-Baqarah (2): 252

${ }^{47}$ Ahmad Tohari, dkk, Al-Qur'an dan Terjemahnya: Bahasa Jawa Banyumasan, 60.
} 


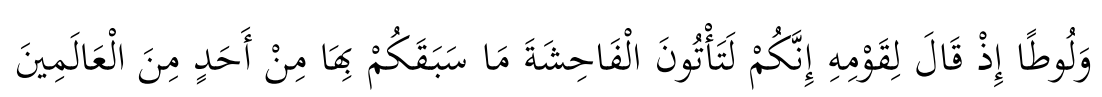

Lan (élinga) rikala Lut Ngucap maring kaumé, ko kabé nyata-nyata nglakoni penggawéan sing njijihi banget njambu/lanang dhemen lanang) sing urung nglakon dépergawé déning sewiji baé sekang umat-umat seurungé ko kabéh. ${ }^{48}$

Ketiga, terdapat beberapa bahasa Jawa Banyumasan yang memiliki perangai yang nyaris sama di bagian pengucapan. Akan tetapi pada bagian penulisan dan makna berbeda. ${ }^{49}$ Seperti pada kata wedi yang bermakna takut dan wedhi yang bermakna pasir. Sebagai contoh sebagai berikut:

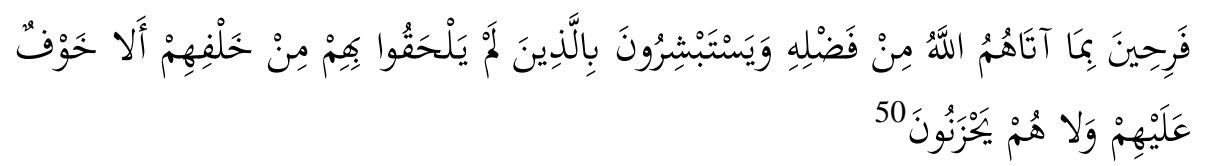

dhéwéke padha seneng-seneng karo kanugrahan sing déparingna déning Gusti Allah maring dhéwéke kabeh, lan atiné bungah maring wong sing ésih keri ning mburi seng urung nyusul dhéwéke, senyatané ora nana rasa wedi munggah dhéwéke lan dhéwéke kabéh ora susah neng ati. $^{51}$

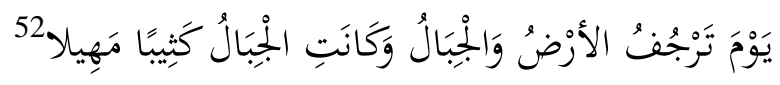

(Élinga) neng dina (rikala) bumi karo gunung-gunung gonjangganjing serosané, lan ndadékna gunung-gunung kuwé kaya umbukan wedhi seng desuntek. ${ }^{53}$

\section{Sistematika Penulisan}

Alquran dan Terjemahnya; Bahasa Banyumas diterjemahkan dengan sistematika Tartib Mushafi. ${ }^{54}$ Adapun urutan ayat dan surat disesuaikan dengan Mushaf Usmani. $^{55}$ Tulisan Arabnya ditulis sebagaimana pada penulisan Alquran dengan

\footnotetext{
${ }^{48}$ Ibid., 536.

${ }^{49}$ Wawancara dengan Ahmad Muttaqin, di ruang IAIN Purwokerto pada tanggal 27 Agustus pukul 13.30 wib

${ }^{50}$ Q.S. Ali Imran (3): 170.

${ }^{51}$ Ahmad Tohari, dkk, Al-Qur'an dan Terjemahnya: Bahasa Jawa Banyumasan, 89.

${ }^{52}$ Q.S. Al-Muzzammil (73): 14

${ }^{53}$ Ahmad Tohari, dkk, Al-Qur'an dan Terjemahnya: Bahasa Jawa Banyumasan, 812.

${ }^{54}$ Dikatakan bahwa tartib surah itu tauqifi dan ditangani langsung oleh Nabi sebagaimana diberitakan Jibril kepadanya atas perintah Tuhan. Dengan demikian, Quran pada masa Nabi telah tersusun surah-surahnya secara tertib, sebagaimana tertib ayat-ayatnya, seperti yang ada di tangan kita sekarang ini, yaitu tartib mushaf Usman yang tidak ada seorang sahabatpun yang menantangnya. Lihat, Manna Khalil al-Qattan, Studi Ilmu-Ilmu Al-Qur'an, 205. Tartib mushafi di awali dari Q.S. Al-fatihah dan di akhiri dengan surat an-Nas.

${ }^{55}$ Mushaf Usmani dinamakan pada periode terakhir atau periode ketiga pengumpulan Al-Qur'an. Kata "Usmani" dinisbahkan kepada tokoh utama dalam pembukuan Al-Qur'an ini yaitu Usman bin
} 
menggunakan Rasm Usmani. ${ }^{56}$ Terjemahan ini dicetak sebanyak dua kali cetakan pertama pada bulan Desember tahun 2015 oleh percetakan Puslitbang Lektur dan Khazanah Keagamaan dengan cover warna merah. Cetakan kedua pada bulan Desember tahun 2016 oleh percetakan IAIN Purwokerto dengan cover warna hijau. Halaman awal di mulai dari sebelah kiri seperti pada buku-buku biasanya. Terjemahan ini terdiri dari 903 halaman yang meliputi halaman romawi sebanyak 18 dan halaman angka sebanyak 885. Pada halaman romawi terdiri dari beberapa bagian:

a. Halaman i berisikan lembar cover.

b. Halaman ii berisikan lembar KDT.

c. Halaman ke iii sampai iv berisikan lembar sambutan Menteri Agama Republik Indonesia yaitu Lukman Hakim Saifuddin. Dalam sambutannya ia menyampaikan rasa syukur atas terbitnya terjemahan Alquran dan Terjemahnya; Bahasa Banyumas. Ia juga menyampaikan terima kasih kepada pihak-pihak yang berperan dan berpartisipasi dalam menyelesaikan tugas terjemahan ini.

d. Halaman v sampai vi berisikan lembar sambutan Kepala Badan Litbang dan Diklat Kementrian Agama yaitu Prof. H. Abd. Rahman Mas’ud, Ph.D. Dalam sambutanya ia menyampaikan alasan terbitnya Alquran dan Terjemahnya; Bahasa Banyumas. Ia juga menyampaikan orientasi penerjemahan Alquran bahasa daerah ini kepada beberapa tujuan di antaranya yaitu: 1) Memperkaya khazanah penerjemahan Alquran ke dalam Bahasa Daerah; 2) memperluas dan memperluas pemahaman Alquran bagi masyarakat pengguna bahasa daerah (bahasa ibu); 3) melestarikan bahasa daerah sebagai bagian dari sistem budaya lokal untuk menghindari

Affan. Terbentuknya Mushaf Usmani menghasilkan standarisasi bacaan Al-Qur'an. Standarisasi dalam kamus besar Bahasa Indonesia adalah penyusunan bentuk (ukuran kualitas) dengan pedoman yang ditetapkan. Dalam sejarah terbentuknya Mushaf Usmani, standarisasi diartikan menutup semua perbedaan dalam bacaan Al-Qur'an, adanya kesatuan secara total yang ada pada teks Al-Qur'an diseluruh dunia. Lihat, Taufik Adnan Amal, Rekonstruksi Sejarah Al-Qur'an (Jakarta: Pustaka Alvabet, 2005), 235.

${ }^{56}$ Seara etimologi, rosm berarti الادر yang bermakna bekas, peninggalan. Dalam perbendaharaan

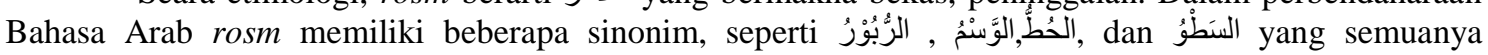
memiliki arti sama, yaitu tulisan. Usmani, dengan ya nisbah dalam disiplin gramatikal Bahasa Arab adalah penisbatan terhadap nama khalifah ketiga, Usman bin Affan. Dengan demikian menurut bahasa, Rosm Usmani dapat dimaknai sebagai bekas penulisan Al-Qur'an yang polanya pernah dibakukan pada masa Khalifah Usman bin Affan. Makna lain adalah cara penulisan Al-Qur'an yang telah disetujui oleh Usman bin Affan pada waktu penulisan mushaf. Lihat, Zainal Arifin, "Mengenal Rasm Usmani; Sejarah, Kaidah, dan Hukum Penulisan Al-Qur'an dengan Rasm Usmani”, Suhuf, Vol. 5, No. 1, (2012), 3. Manna al-Qattan mendefinisikan bahwa Rosm Usmani merupakan pola penulisan Al-Qur'an yang lebih menitik beratkan pada metode (thariqah) tertentu yang digunakan pada waktu kodifikasi mushaf pada zaman khalifah Usman yang dipercayakan kepada Zaid bin Tsabit bersama tiga orang Quraisy yang disetujui Usman. Lihat, Manna Khalil al-Qattan, Studi Ilmu-Ilmu Al-Qur'an, 205. 
kepunahannya, dan 4) mempermudah penerapan ajaran yang terkandung dalam Alquran.

e. Halaman vii sampai ix berisikan lembar pengantar Kepala Puslitbang Lektur dan Khazanah Keagamaan Badan Litbang dan Diklat Kementrian Agama yaitu Choirul Fuad Yusuf. Dalam pengantarnya ia menyampaikan tujuan dicetaknya Alquran dan Terjemahnya: Bahasa Banyumas yaitu sebagai salah satu upaya pengelolaan "kekayaan bangsa" dan pelestarian budaya daerah dan juga untuk penguatan pelayanan keagamaan bagi umat.

f. Halaman xi sampai xii berisikan lembar sambutan rektor IAIN Purwokerto yaitu Dr. H. A. Lutfi Hamidi, M.Ag. Dalam sambutannya ia menyampaikan pertama, syukur dan ucapan terima kasih kepada pihak-pihak yang ikut berperan dalam penerjemahan ini. Kedua, Alquran terjemahan Banyumas memiliki kecenderungan populis. ${ }^{57}$ Ketiga, peran IAIN Purwokerto sebagai Perguruan Tinggi Keagamaan Islam Negeri yang memiliki tanggung jawab membangun komunikasi antara pengetahuan Islam dengan unsur-unsur lain yang secara kolektif membentuk peradaban sosial.

g. Halaman xv sampai xvii berisikan lembar daftar surah beserta halaman.

Pada halaman angka berisikan lembaran isi mulai dari halaman 1 sampai 885 . Pada bagian isi sebelah kanan merupakan ayat Alquran adapun di bagian kiri merupakan terjemahannya. Pada halaman terakhir terdapat tanda tashih oleh lajnah pentashih mushaf Alquran (LPMA) Kementrian Agama Republik Indonesia yang diketuai oleh Dr. H. Muchlish Muhammad Hanafi dan sekretaris oleh Dr. H. Akhsin Sakho Muhammad.

\section{Kualitas Alqurandan Terjemahnya: Bahasa Jawa Banyumasan \\ a. Ketepatan Terjemahan}

Ketepatan terjemahan yang dimaksud di sini adalah kesesuaian antara pesan yang terdapat dalam Alquran dan pesan yang terdapat dalam terjemahan Alquran bahasa Jawa Banyumasan. Sejauh penelusuran peneliti terdapat beberapa hal yang kurang tepat dalam penerjemahan yang dilakukan oleh tim penerjemah, di antaranya yaitu terletak pada saat tim penerjemah menerjemahkan kata alaisa. Kata alaisa dalam Alquran

\footnotetext{
${ }^{57}$ Ahmad Tohari, dkk, Al-Qur'an dan Terjemahnya: Bahasa Jawa Banyumasan, xi-xii.
} 
disebutkan sebanyak 13 kali. Penulis menemukan dua bentuk ketidaktepatan yaitu pada ayat berikut ini:

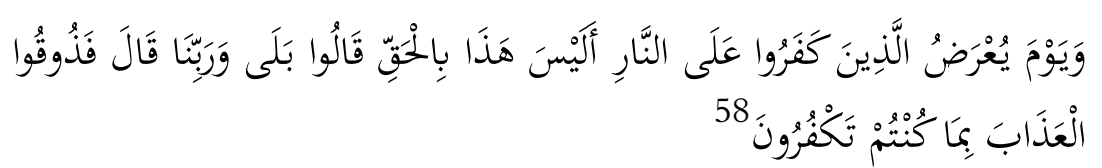

Terjemahan Kemenag: Dan( ingatlah) pada hari (ketika) orangorang yang kafir dihadapkan kepada mereka, (mereka akan ditanya), "bukankah (azab)ini benar?”mereka menjawab, "ya benar, demi Tuhan kami." Allah berfirman, "maka rasakanlah azab ini, karena dari dulu kamu mengingkarinya." 59

Terjemahan Banyumas: Lan (élinga) neng dina (rikala) wong-wong sing kapir déadhepna maring dhéwéké kabéh (dhéwéké arep padha détakoni), "apa ora siksa kiyé nyata?" dhéwéké padha semaur, "nggih nyata, sekawit (sekawit) pangérané kula sami." Gusti Allah dhawuh, "mangka raksakna siksa kiyé, merga gemiyén ko padha ngingkari kuwé." 60

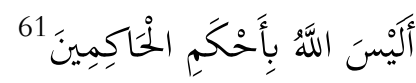

Terjemahan Kemenag: Bukankah Allah hakim yang paling adil $?^{62}$

Terjemahan Banyumas: Mbok ya Gusti Allah hakim sing paling adil? ${ }^{63}$

Laisa merupakan bentuk fi'il bermakna bukan ketambahan huruf istifham berbentuk I (alif) yang bermakna apakah. Dengan demikian kata alaisa memiliki makna bukankah. Kata bukankah tidak tepat jika diterjemahkan ke dalam bahasa Banyumas menjadi apa ora dan mbok ya. Apa ora merupakan bentuk pertanyaan yang menekankan pada jawaban "tidak" seperti contoh pertanyaan "apa ora lunga?" maka jawabannya "ora kiye". Maka tidak tepat jika ayat di atas diterjemahkan apa ora karena ayat di atas merupakan pertanyaan yang jawabnya berbentuk "iya". Menurut penulis terjemahan yang tepat adalah mbok iya.

Tim penerjemah menerjemahkan kata "bukankah" pada ayat kedua menjadi mbok ya kurang tepat karena kata mbok ya pada ayat tersebut bisa bermakna" seyogianya" jika reseptor membacanya tanpa menggunakan logat banyumasan. Penulis berpendapat

\footnotetext{
${ }^{58}$ Q.S. Al-Ahqaaf (46): 34.

${ }^{59}$ Kemenag, Al-Qur'an dan Terjemahnya, 506.

${ }^{60}$ Ahmad Tohari, dkk, Al-Qur'an dan Terjemahnya: Bahasa Jawa Banyumasan, 697.

${ }^{61}$ Q.S. At-Tin (95): 8.

${ }^{62}$ Kemenag, Al-Qur'an dan Terjemahnya, 597.

${ }^{63}$ Ahmad Tohari, dkk, Al-Qur'an dan Terjemahnya: Bahasa Jawa Banyumasan, 864.
} 
bahwa kata tersebut lebih tepat jika diterjemahkan menjadi "Mbok iya". Mengingat semua reseptor tidak pasti membacanya dengan menggunakan logat banyumasan sekalipun yang membaca adalah orang Banyumas itu sendiri.

Sedangkan bentuk ketepatan tim penerjemah menerjemahkan kata alaisa bisa dilihat pada beberapa contoh ayat di bawah ini:

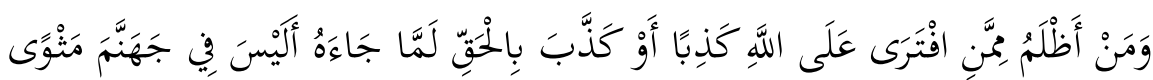

$$
\begin{aligned}
& 64 \text { لِنْكَافِرِينَ }
\end{aligned}
$$

Terjemahan Kemenag: Dan siapakah yang lebih zalim daripada orang yang mengada-adakan kebohongan kepada Allah atau orang yang mendustakan yang hak ketika (yang hak) itu datang kepadanya? Bukankah dalam nerakaJahanam ada tempat bagi orang-orang kafir? $^{65}$

Terjemahan Banyumas: Lan sapa seng lewih aniaya (dolim) tenimbang wong seng ngana-anakna penggorohan maring Gusti Allah utawa wong sing nggorohna sing hak (bener) rikala (sing apik) kuwé butul maring dhéwéké? Mbok iya neng neraka Jahanam ana panggonan nggo wong-wong sing mbangkang (kapir)? ${ }^{66}$

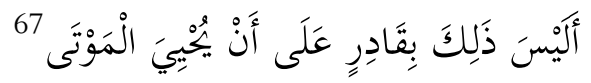

Terjemahan Kemenag: Bukankah (Allah yang berbuat) demikian berkuasa (pula) menghidupkan orang mati? ${ }^{68}$

Terjemahan Banyumas: Mbok iya (Gusti Allah seng temindak) kaya kuwé (uga) kewasa nguripna wong mati? ${ }^{69}$

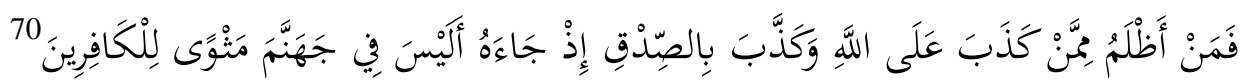

Terjemahan Kemenag: Maka siapakah yang lebih zalim daripada orang-orang yang membuat-buat kebohongan terhadap Allah dan mendustakan kebenaran yang datang kepadanya? Bukankah di neraka Jahanam tempat tinggal bagi orang-orang yang kafir? ${ }^{71}$

Terjemahan Banyumas: Mangka sapa sing lewih aniaya (dolim) tenimbang wong sing padha gawé-gawé goroh maring Gusti Allah lan nggorohna bebener seng teka maring dhéwéké? Mbok iya neraka

\footnotetext{
${ }^{64}$ Q.S. Al-Ankabut(29): 68.

${ }^{65}$ Kemenag, Al-Qur'an dan Terjemahnya, 404.

${ }^{66}$ Ahmad Tohari, dkk, Al-Qur'an dan Terjemahnya: Bahasa Jawa Banyumasan, 542.

${ }^{67}$ Q.S. Al-Qiyamah (75): 40

${ }^{68}$ Kemenag, Al-Qur'an dan Terjemahnya, 578.

${ }^{69}$ Ahmad Tohari, dkk, Al-Qur'an dan Terjemahnya: Bahasa Jawa Banyumasan, 820.

${ }^{70}$ Q.S. Az-Zumar (39): 32

${ }^{71}$ Kemenag, Al-Qur'an dan Terjemahnya, 461.
} 
Jahanam papan panggonané wong-wong sing padha mbangkang (kapir) $?^{72}$

Bentuk kekurangtepatan lain oleh tim penerjemah yaitu ketika menerjemahkan allazina kafaru. Contohnya sebagai berikut:

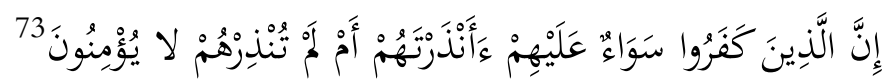

Terjemahan Kemenag: Sesungguhnya orang-orang kafir, sama saja bagi mereka, engkau (Muhammad) beri peringatan atau tidak engkau beri peringatan, mereka tidak akan beriman. ${ }^{74}$

Terjemahan Banyumas: Setemené wong-wong kapir (mbangkang), padha baé tumprap dhéwéké, sliramu (Muhammad) paring pepénget utawa ora sliramu paring pepénget. Dhéwéké kabéh ora bakal percaya. $^{75}$

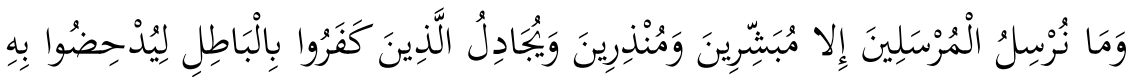

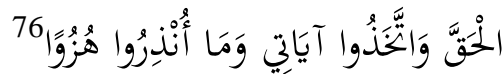

Terjemahan Kemenag: Dan kami tidak mengutus rasul-rasul melainkan sebagai pembawa kabar gembira dan pemberi peringatan; tetapi orang yang kafir membantah dengan (cara) yang batil agar dengan demikian mereka dapat melenyapkan yang hak (kebenaran), dan mereka menjadikan ayat-ayat-Ku dan apa yang diperingatkan terhadap mereka sebagai olok-olokan. ${ }^{77}$

Terjemahan Banyumas: Lan ingsun ora ngutus rasul-rasul kejaba nggo ngawa werta bebungah lan awéh pengéling-éling; ning wong sing padha mbangkang (kapir) mbantah kanthi (cara) sing ora bener supaya kanthi kuwé dhéwéké bisa ngilangna perkara sing hak (bebener), lan dhéwéké padha ndadékna ayat-ayat ingsun lan apa sing dépemutna maring wong-wong kuwé dadi perguyon. ${ }^{78}$

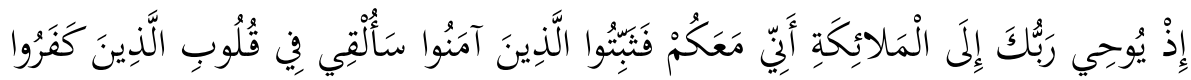

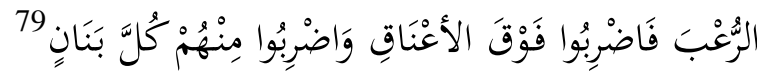

Terjemahan Kemenag: (Ingatlah), ketika Tuhanmu mewahyukan kepada para malaikat, "sesungguhnya aku bersama kamu, maka teguhkanlah (pendirian) orang-orang yang telah beriman.” Kelak

\footnotetext{
${ }^{72}$ Ahmad Tohari, dkk, Al-Qur'an dan Terjemahnya: Bahasa Jawa Banyumasan, 633.

${ }^{73}$ Q.S. Al-Baqarah (2): 6

${ }^{74}$ Kemenag, Al-Qur'an dan Terjemahnya, 3.

${ }^{75}$ Ahmad Tohari, dkk, Al-Qur'an dan Terjemahnya: Bahasa Jawa Banyumasan, 2.

${ }^{76}$ Q.S. Al-Kahfi (18): 56.

${ }^{77}$ Kemenag, Al-Qur'an dan Terjemahnya, 300.

${ }^{78}$ Ahmad Tohari, dkk, Al-Qur'an dan Terjemahnya: Bahasa Jawa Banyumasan, 388.

${ }^{79}$ Q.S. Al-Anfal (8): 12.
} 
akan aku berikan rasa ketakutan ke dalam hati orang-orang kafir, maka pukullah di atas leher mereka dan pukullah tiap-tiap ujung jari mereka. ${ }^{80}$

Terjemahan Banyumas: (Élinga) rikala Pangéranmu mahyokna maring para malaékat, "setemené ingsun bareng karo ko kabéh, mangka kuwatna (tekad) wong-wong seng wes percaya." Mbésuk bakal ingsun paring rasa wedi maring njero atiné wong-wong sing mbangkang (kapir), mangka gebunga neng sendhuwur guluné dhéwéké lan thuthuka saben-saben pucuk jenthiké dhéwéké kabéh. ${ }^{81}$

Kata kafaru memiliki makna menutupi, kufur dalam arti melawan Allah, ${ }^{82}$ dan mengingkari. ${ }^{83}$ Dalam lisanul Arab kata kafaru bermakna tidak percaya yang berlawanan dengan kata iman (percaya), orang yang mengingkari Allah dan mencegah hal-hal yang datangnya dari Allah. ${ }^{84}$ Kata allazina kafaru bagi penulis kurang tepat jika diterjemahkan menjadi wong-wong sing mbangkang. Dalam kamus bahasa Jawa mbangkang memiliki makna pendurhakaan. Sedangkan pendurhakaan dalam Kamus bahasa Indonesia merupakan kata benda yang berarti perbuatan durhaka terhadap Tuhan, orang tua dan sebagainya bisa juga berarti pemberontakan terhadap kekuasaan yang sah.

Adapun kafir dalam Kamus Bahasa Indonesia merupakan kata sifat serapan dari bahasa Arab yang berarti tidak percaya kepada Allah dan rasulnya. Kata pendurhakaan sifatnya lebih umum bisa ditujukan kepada selain kepada Allah sedangkan kata kafir sifatnya lebih khusus hanya ditujukan kepada Allah. Sehingga kata allazina kafaru akan lebih tepat jika diterjemahkan menjadi wong-wong kafir. Di samping kata tersebut sudah diserap ke dalam bahasa Indonesia, konteks kata yang diterjemahkan juga merupakan nas keagamaan.

Tim penerjemah melakukan penerjemahan dengan tepat di beberapa ayat lain. Akan tetapi model penerjemahan seperti itu tetap dilakukannya. Artinya, terdapat ketidakkonsistenan dalam penerjemahan. Contoh ketepatan tersebut adalah sebagai berikut:

${ }^{80}$ Kemenag, Al-Qur'an dan Terjemahnya, 178.

${ }^{81}$ Ahmad Tohari, dkk, Al-Qur'an dan Terjemahnya: Bahasa Jawa Banyumasan, 225.

${ }^{82}$ Ahmad Warson Munawwir, Al-Munawwir; Kamus Arab Indonesia, 1218.

83 Atabik Ali dan Ahmad Zuhdi Muhdlor, Kamus Kontemporer Arab-Indonesia, Cet. 4 (Yogyakarta: Multi Karya Grafika Pondok Pesantren Krapyak, 1998), 1512.

${ }^{84}$ Ibn Manzir, Lisan al-Arab, 3897. 
85

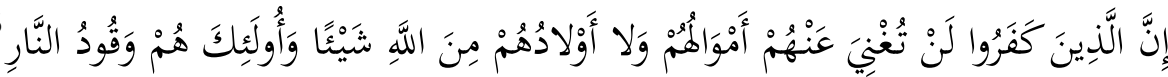

Terjemahan Kemenag: Sesungguhnya orang-orang yang kafir, bagi mereka tidak akan berguna sedikit pun harta benda dan anak-anak mereka terhadap (azab) Allah. Dan mereka itu (menjadi) bahan bakar api neraka. $^{86}$

Terjemahan Banyumas: Setemene wong-wong sing kapir, tumprap dhéwéké ora gadhang migunani babar-blas bandha lan anak-anaké mungguh (siksané) Gusti Allah. Lan dhéwéké mau padha (dadi) uruburubé geni neraka. ${ }^{87}$

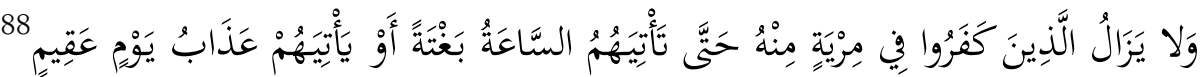

Terjemahan Kemenag: Dan orang-orang kafir itu senantiasa ragu mengenai hal itu (Alquran), hingga saat (Kematiannya) datang kepada mereka dengan tiba-tiba, atau azab hari Kiamat yang datang kepada mereka. ${ }^{89}$

Terjemahan Banyumas:Lan wong-wong kapir kuwé tansah mamang ngenani perkara kuwé (Alquran) batul wektu (matiné) teka maring dhéwéké kabéh kanthi dadakan, utawa siksa dina Kiyamat sing teka maring dhéwéké kabéh. ${ }^{90}$

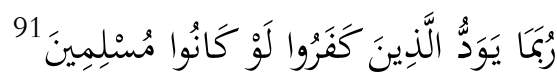

Terjemahan Kemenag: Orang kafir itu kadang-kadang (di akhirat) menginginkan, sekiranya mereka dahulu (di dunia) menjadi orang Muslim. ${ }^{92}$

Terjemahan Banyumas: Wong-wong kapir kuwé kala-kala (mengko neng akhérat) kepéngin, énggané gemiyén( neng ndunya) dhéwéké padha dadi wong Muslim. ${ }^{93}$

\section{b. Kejelasan Terjemahan}

Teori mengukur kejelasan terjemahan dilakukan melalui ketepatan dalam menyusun kalimat, panjang kalimat, pemakaian ejaan dan diksi. Berkaitan dengan itu, penulis menemukan beberapa penerjemahan tim penerjemah yang menurut penulis kurang jelas jika dilihat dari empat aspek tersebut.

\footnotetext{
${ }^{85}$ Q.S. Ali Imran (3): 10.

${ }^{86}$ Kemenag, Al-Qur'an dan Terjemahnya, 51.

${ }^{87}$ Ahmad Tohari, dkk, Al-Qur'an dan Terjemahnya: Bahasa Jawa Banyumasan, 61.

${ }^{88}$ Q.S. Al-Hajj (22): 55.

${ }^{89}$ Kemenag, Al-Qur'an dan Terjemahnya, 338.

${ }^{90}$ Ahmad Tohari, dkk, Al-Qur'an dan Terjemahnya: Bahasa Jawa Banyumasan, 446.

${ }^{91}$ Q.S. al-Hijr (15): 2.

${ }^{92}$ Kemenag, Al-Qur'an dan Terjemahnya, 262.

93 Ahmad Tohari, dkk, Al-Qur'an dan Terjemahnya: Bahasa Jawa Banyumasan, 335.
} 
1) Ketepatan dalam Penyusunan dan Panjang Kalimat

Berkaitan dengan ketepatan penyusunan kalimat, penulis menemukan ketidaktepatan tim penerjemah ketika menerjemahkan ayat berikut:

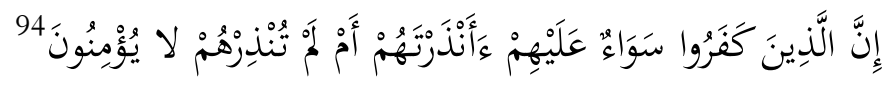

Terjemahan Kemenag: Sesungguhnya orang-orang kafir ${ }_{2}$ sama saja bagi mereka, engkau (Muhammad) beri peringatan atau tidak engkau beri peringatan, mereka tidak akan beriman. ${ }^{95}$

Terjemahan Banyumas: Setemené wong-wong kapir (mbangkang), padha baé tumprap dhéwéké, sliramu (Muhammad) paring pepénget utawa ora sliramu paring pepénget. Dhéwéké kabéh ora bakal percaya. $^{96}$

Persoalan ayat di atas adalah penjelasan bahwa kapir bisa dimaknai mbangkang. Berkaitan dengan itu tim penerjemah menambahkan keterangan mbangkang dalam penerjemahannya yang ada dalam tanda kurung. Meskipun kata tersebut dapat dipahami akan tetapi dalam konteks penerjemahan ini tim penerjemah telah memberikan keterangan kata kapir dalam sebuah footnote. Selain itu antara kata kapir dan mbangkang memiliki kelas kata yang berbeda. Kapir merupakan kata sifat dan mbangkang merupakan kata benda.

\section{2) Pemakaian Ejaan}

Ada beberapa ejaan yang kurang tepat dalam terjemahan Banyumas ini. Umumnya pada penulisan kata serapan yang kurang tepat atau kata/istilah asing yang memang belum disempurnakan ke dalam bahasa Indonesia. Beberapa contoh kekurangtepatan pada aspek ejaan ini adalah saat tim penerjemah menerjemahkan ayatayat berikut:

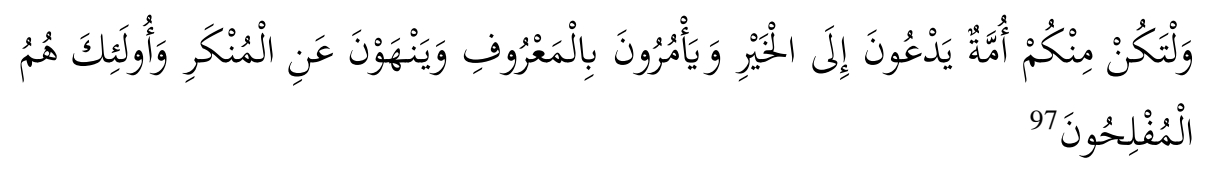

Terjemahan Kemenag: Dan hendaklah di antara kamu ada segolongan orang yang menyeru kepada kebajikan, menyeru (berbuat) yang makruf, dan mencegah dari yang mungkar. Dan mereka itulah orang-orang yang beruntung. ${ }^{98}$

\footnotetext{
${ }^{94}$ Q.S. Al-Baqarah (2): 6

${ }^{95}$ Kemenag, Al-Qur'an dan Terjemahnya, 3.

${ }^{96}$ Ahmad Tohari, dkk, Al-Qur'an dan Terjemahnya: Bahasa Jawa Banyumasan, 2.

${ }^{97}$ Q.S. Ali Imran (3): 104.

${ }^{98}$ Kemenag, Al-Qur'an dan Terjemahnya, 63.
} 
Terjemahan Banyumas: Lan preyogané neng antarané ko kabéh ana segolongan wong sing diajek-ajek maring kebagusan, préntah (nglakoni) sing apik (ma'ruf) lan nyegah maring sing ala (mungkar) lan dhéwéké mau klebu maring wong-wong sing begya. ${ }^{99}$

Kesalahan ejaan yang dilakukan oleh tim penerjemah dalam menuliskan redaksi terjemahanya adalah penulisan kata ma'ruf. Kata ma'ruf seharusnya ditulis dengan dimiringkan ma'ruf. Dalam konteks ini karena ma'ruf merupakan kata asing sehingga ejaan tersebut harus dimiringkan kecuali jika penerjemah menuliskan kata ma'ruf yang sudah diadopsi ke dalam bahasa Indonesia yaitu makruf. Selain itu kesalahan penulisan huruf kapital pada kata firdos dalam Q.S. al-kahfi (18): 107. Meskipun istilah firdos berhubungan dengan perihal keagamaan, namun dalam tatatulis bahasa Indonesia istilah tersebut harus ditulis dengan huruf kecil.

\section{c. Kewajaran Terjemahan}

Terjemahan yang berkualitas memiliki tiga ciri utama, yaitu tepat, jelas, dan wajar. Tepat adalah amanat yang terdapat dalam nas sumber itu sama dengan amanat yang terdapat dalam terjemahnya, sedangkan jelas berarti terjemahan itu mudah dipahami maknanya, dan wajar berarti bahasa terjemahan itu lancer, wajar, dan tidak terasa ada keganjilan. ${ }^{100}$ Secara umum terjemahan Banyumas dapat dinilai wajar. Akan tetapi terdapat sedikit koreksi pada terjemahan Banyumas. Pertama, terdapatnya beberapa ayat yang kurang tepat diterjemahkan oleh tim Penerjemah, seperti pada contoh sub bab pembahasan ketepatan terjemahan. Sehingga ada beberapa penerjemahan ayat yang bagi penulis tidak ekuivalen. Kedua, terdapat kesalahan ejaan penulisan bahasa asing. Akan tetapi bagi penulis kesalahan tersebut tidak begitu berdampak pada pemahaman.

\section{Respon Masyarakat atas Hadirnya Alquran dan Terjemahnya: Bahasa Jawa Banyumasan}

Alquran dan Terjemahannya; Bahasa Jawa Banyumasan merupakan pengalihan dari terjemahan Alquran Kementrian Agama tahun 2010. Pada tahun 2014 terjemahan ini dicetak oleh Puslitbang Lektur dan Khazanah Keagamaan Kementrian Agama sebanyak kurang lebih 500 eksemplar. 200 eksemplar

99 Ahmad Tohari, dkk, Al-Qur'an dan Terjemahnya: Bahasa Jawa Banyumasan, 77.

${ }^{100}$ Syihabudddin, Teori dan Praktik Penerjemahan Arab Indonesia, 207. 
diminta oleh Ketua Menteri Agama untuk dibagikan di pesantren-pesantren, dan 300 eksemplar di bagikan dikalangan akademisi dan pejabat pemerintah.

Tahun 2015 IAIN Purwokerto mencetak lagi untuk dibagikan di daerah-daerah khusus yang menggunakan bahasa Jawa Banyumasan. Daerah tersebut yaitu Tegal, Brebes, Cilacap, Banyumas (Purwokerto), Banjarnegara, Purbalingga, Kebumen, dan Wonosobo. Akan tetapi pendistribusian hanya terbatas pada Pesantren dan Lembaga Pendidikan saja, belum merambah ke komunitas yang menjadi sasaran. Sementara di Banyumas (Purwokerto) pendistribusian sudah sampai di masyarakat abangan akan tetapi yang mendapat hanya perorangan belum sampai kelompok masyarakat abangan.

Latar belakang penerjemahan ini berawal dari masyarakat abangan yang tidak familiar dengan Alquran, tidak terbiasa membaca Alquran dan tidak paham juga dengan terjemahan yang berbahasa Indonesia (bukan bahasa sehari-hari). Fenomena ini yang kemudian mendorong munculnya terjemahan Alquran dengan bahasa Banyumasan. Terjemahan ini disusun sebaik mungkin guna bermanfaat bagi komunitas abangan.

Berbicara tentang respons, berarti berbicara tentang tanggapan masyarakat. ${ }^{101}$ Tanggapan masyarakat dapat diketahui jika terjemahan ini sudah menyebar di lapisan masyarakat. Kendalanya kemudian adalah penyebaran atau pendistribusian terjemahan ini ternyata belum sampai di kelompok masyarakat, lebih khusus masyarakat abangan yang menjadi sasaran utama. Berdasarkan kendala tersebut penulis membidik beberapa ayat untuk dijadikan instrumen mengetahui respons masyarakat. Penulis menyebar kuesionernya ke tiga tempat di wilayah Banyumas yaitu pasar terminal dan persawahan desa Dukuhwaluh, kecamatan Kembaran. Masing-masing tempat tersedia sebanyak 10 responden.

Terkumpul sebanyak 30 responden, dari masing-masing tempat yang mempunyai respon berbeda-beda. Ketika penulis menyebar kuesioner di pasar. Penulis mendatangi beberapa kalangan masyarakat yang berumur kisaran 37-74 tahun. Responden

${ }^{101}$ Pembahasan kali ini hampir sama dengan karya yang ditulis oleh Jajang A. Rohmana dengan judul Alquran dan Bahasa Sunda Populer: Respon Generasi Milenial Terhadap Terjemahan Alquran Bahasa Sunda, menjelaskan mengenai respon masyarakat terhadap penerjemahan Alquran, perbedaanya sasaran yang dituju oleh Jajang adalah masyarakat generasi milenial. Adapun hasil penelitian ini menunjukan bahwa terjemahan Sunda dalam Al-Qur'an Miwah Tarjamahna dianggap kurang bisa memuaskan pemahaman mereka. Seperti yang dikutip oleh Jajang yang dalam bahasa Catfrod disebut sebagai salah satu problem utama penerjemahan, yaitu terkait dengan ragam bahasa yang lama (arkhais), baik dalam bahasa sumber maupun bahasa sasaran. Bahasa arkhais memunculkan masalah bagaimana penerjemah harus mencari dan memilih ragam variasi bahasa yang tepat dalam bahasa sasaran. Lihat Jajang A. Rohmana, "Alquran dan Bahasa Sunda Populer: Respon Generasi Milenial Terhadap Terjemahan Alquran Bahasa Sunda”, Al-Bayan: Studi Al-Qur'an dan tafsir, Vol. 4, No. 2, 2019, 108. 
masyarakat pasar yang memilih tingkat keterbacaan "sulit" hanya ada satu. Alasannya adalah membaca terjemahan Alquran bahasa Banyumas penalarannya lebih sulit dibandingkan Alquran terjemahan bahasa Indonesia. Harus dibaca berkali-kali untuk memperoleh pemahaman maknanya.

Selain satu responden tersebut sembilan responden memilih tingkat keterbacaan "mudah". Pasalnya memahami dengan bahasa Banyumas menurut mereka jauh lebih memudahkan. Asumsi penulis dua tanggapan masyarakat tersebut terkait dengan umur. Pasalnya ketika penulis menyebar kuesioner ke orang yang umurnya lebih muda perlu ada pemahaman lebih untuk mencari makna yang terkandung.

Responden dari terminal ada dua orang yang memilih tingkat keterbacaan "sulit" dengan alasan pertama, ketika muda tidak sekolah sehingga tidak bisa membaca dan sulit untuk memahami pesan tulis. Alasan kedua, adalah banyak kata yang tidak sesuai dengan bahasa keseharian sehingga sulit untuk dipahami. Selain dua responden ini delapan responden memilih tingkat keterbacaan "mudah".

Terakhir dari responden petani, sepuluh responden dari petani memilih tingkat keterbacaan "mudah". Akan tetapi salah satu dari responden ini memberi masukan bahwa kata Allah tidak tepat jika di terjemahkan menjadi ingsun karena jika yang membaca orang-orang awam ditakutkan menjadi salah pemahaman. Bisa dikatakan bahwa hanya $10 \%$ responden yang memilih tingkat keterbacaan sulit dan $90 \%$ responden memilih tingkat keterbacaan mudah.

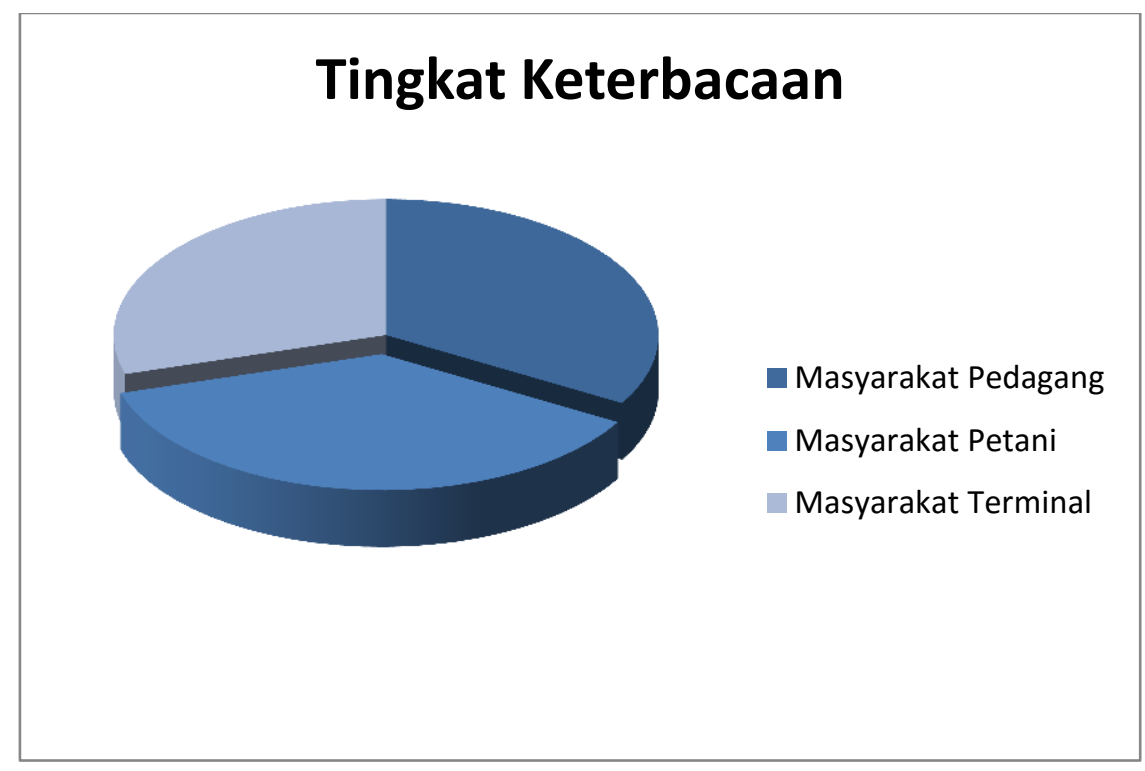

Ragaan 2 
Berdasarkan ragaan di atas penulis menilai bahwa terjemahan Alquran bahasa Jawa Banyumasan bagus. Sebab setelah penulis amati berdasarkan penyebaran kuesioner banyak masyarakat yang memilih tingkat keterbacaan "mudah". Penilaian tingkat keterbacaan mudah menandakan bahwa tingkat keberterimaan masyarakat juga pasti "diterima". Sayangnya tujuan untuk mendekatkan komunitas abangan pada Alquran belum terwujud karena penyebaran terjemahan tersebut belum sampai di lapisan masyarakat abangan.

\section{Kesimpulan}

Penelitian ini akan diarahkan untuk dapat menjawab dua rumusan masalah yang penulis angkat dalam Analisis Genetik-Objektif atas Alquran dan Terjemahnya: Bahasa Jawa Banyumasan Karya Tim Penerjemah IAIN Purwokerto. Pertama, untuk melihat karakteristik Alquran dan Terjemahnya: Bahasa Jawa Banyumasan. Kedua, untuk melihat respons masyarakat Banyumas dengan hadirnya terjemahan Alquran dalam bahasa Banyumas.

Menjawab pertanyaan pertama, penulis berkesimpulan bahwa penerjemahan Alquran ke bahasa Banyumas dilakukan dengan metode terjemahan tafsiriyah. Sedangkan jika mengikuti metode penerjemahan dari Newmark terjemahan ini masuk pada metode penerjemahan komunikatif. Ideologi yang dipakai dalam penerjemahan ini adalah domestication yang penerjemahnya mengadaptasi hasil penerjemahan dengan budaya pembaca. Adapun menjawab pertanyaan yang ketiga, kualitas terjemahan ini adalah masuk dalam kategori wajar.

Sedangkan dalam menjawab pertanyaan ketiga, penulis berkesimpulan bahwa dari 30 kuisioner yang penulis sebar sebanyak 90\% masyarakat Banyumas memilih tingkat keterbacaan "mudah". 10\% memilih tingkat keterbacaan sulit dengan alasan karena bahasa yang dipakai dalam terjemahan ini tidak begitu familier di masyarakat. Data tingkat keterbacaan di atas menunjukkan bahwa tingkat keberterimaan terjemahan Alquran ini $90 \%$ juga diterima di kalangan masyarakat. 


\section{Daftar Pustaka}

\section{Buku}

Ali, Atabik dan Ahmad Zuhdi Muhdlor, Kamus Kontemporer Arab-Indonesia, Cet. 4, Yogyakarta: Multi Karya Grafika Pondok Pesantren Krapyak, 1998

Al-Qaț̣ān, Mannā' Khalīl, Studi Ilmu-Ilmu Al-Qur'an, terj. Mudzakir, Bogor: Litera Antar Nusa, 2015.

Amal, Taufik Adnan, Rekonstruksi Sejarah Al-Qur'an, Jakarta: Pustaka Alvabet, 2005.

Anwar, Rosihon dan Mukhtar Solihin, Ilmu Tasawuf, Bandung: CV Pustaka Setia, 2004.

Baidan, Nashruddin, Perkembangan Tafsir Alqurandi Indonesia, Solo: Tiga Serangkai Pustaka Mandiri, 2003.

Greetz, Cifford, Agama Jawa; Abangan, Santri, Priyayi dalam Kebudayaan Jawa, terj. Aswab Mahasin dan Bur Rasuanto, Depok: Pustaka Jaya, 2013.

Hadi, Sutrisno, Metodologi Research, Yogyakarta: Offiset, 1995.

Herusatoto, Budiono, Seri Satu Abad Kebangkitan Nasional Banyumas: Sejarah, Budaya, Bahasa, dan Watak, Yogyakarta: LKiS, 2008.

Hidayat, Komaruddin, Memahami bahasa Agama; Sebuah Kajian Hermeunetika, Jakarta: Paramadina, 1996.

Ichwan, Moch. Nur, "Negara Kitab Suci dan Politik Terjemah Resmi Al-Quran di Indonesia, dalam Sadur Sejarah Terjemah di Indonesia dan Malaysia, ed. Henri Cambert-Loir, Jakarta: Kepustakaan Populer Gramedia, 2009.

M, M. Tata Taufik, Terjemah Dari Teori Ke Praktek, Kuningan: al-Ikhlash, 2001.

Manzūr, Ibn, Lisān al-`Arab, juz xii, Beirut: Dar Sadir, 1885.

Munawir, "Alqurandan Terjemahnya Bahasa Jawa Banyumasan (Telaah Karaktersitik dan Konsistensi Terjemahan), dalam Tafsir Alqurandi Nusantara, ed. Ahmad Baidowi, Yogyakarta: Lembaga Ladang Kata, 2020.

Munawwir, Ahmad Warson, Al-Munawwir; Kamus Arab-Indonesia, Surabaya: Pustaka Progressif, 1997.

Nashruddin, Baidan, Wawasan Baru Ilmu Tafsir, Yogyakarta: Pustaka Pelajar, 2016.

Shiddiqi, Nourouzzaman, Fikih Indonesia: Penggagas dan Gagasanya, Yogyakarta: Pustaka Pelajar, 1997.

Subiyanto, Ibnu, Metodologi Penelitian, Yogyakarta: UPP AMP YKPN, 1994.

Sugono, Dendy, (red), Kamus Bahasa Indonesia, Jakarta: Pusat Bahasa, 2008. 
Sukardi, Tanto, Tanam Paksa di Banyumas; Kajian Mengenai Sistem, Pelaksanaan dan Dampak Sosial Ekonomi, Yogyakarta: Pustaka Pelajar, 2014.

Syihabuddin, Teori dan Praktik Penerjemahan Arab-Indonesia, Jakarta: Dirjen Dikti Depdiknas, 2002.

Tohari, Ahmad, Bekisar Merah, Jakarta: Gramedia, 2013.

Trianton, Teguh, Identitas Wong Banyumas, Yogyakarta: Graha Ilmu, 2013.

\section{Skripsi/Tesis}

Oktaviani, Eka Dian, "Biografi Ahmad Tohari Kiprah dan Prestasi Sastrawan Banyumas Tahun 1970-2015", Skripsi, Fakultas Keguruan dan Ilmu Pendidikan Universitas Muhamadiyah Purwokerto, (2015)

Pudail, M.,"Terjemah Alqurandalam Bahasa Mandar”, Skripsi, Fakultas Ushulludin UIN Sunan Kalijaga, Yogyakarta, 2003.

Yahya, Mohamad, "Analisis Genetik Objektif atas Alquranal-Karim: Terjemah Tafsiriyah karya M. Thalib", Thesis, Program Pascasarjana UIN Sunan Kalijaga, Yogyakarta, 2012.

\section{Jurnal}

Anugrahita, Dwiana dan Sudartomo Macaryus, "Identitas Kebanyumasan dalam Penggunaan Bahasa di Ruang Publik”, Caraka, Vol. 1, No. 2, (2015): 60-65.

Arifin, Zainal, "Mengenal Rasm Usmani; Sejarah, Kaidah, dan Hukum Penulisan Alqurandengan Rasm Usmani”, Suhuf, Vol. 5, No. 1 (2012): 169-187.

Hanafi, Muchlis M., "Problematika Terjemahan Al-Qur'an: Studi pada Beberapa penerbitan Alqurandan Kasus Kontemporer”, Suhuf, Vo. 4, No. 2, (2011): 169 195

Hatmiati dan Husin,'Budaya Dalam Penerjemahan Bahasa", Jurnal al-Mi'yar, Vol. 1, No. 2, 2018.

Indriati, Anisah, "Kajian Terjemah Al-Qur'an: Studi Terjemah AlquranBasa Jawi “Assalam” karya Abu Taufiq S”, Maghza, Vol. 1, No. 1, (2012): 1-20.

Istianah, "Dinamika Penerjemahan Al-Qur'an: Polemik Karya Terjemahan an HB Jassin dan Terjemah Tafsiriyah an Muhammad Thalib", Maghza, Vol. 1, No.1, (2016): 41-56.

Jajang A. Rohmana, "Alquran dan Bahasa Sunda Populer: Respon Generasi Milenial Terhadap Terjemahan Alquran Bahasa Sunda", Al-Bayan: Studi Alqurandan tafsir, Vol. 4, No. 2, 2019, 108. 
Kamil, Ahmad Zaidamil, "Tafsir Al-Jalalain dan Bahasa Madura: Lokalitas Kitab terjemahan Tafsir al-Jalalain bi al-Lugah al-Madiriyyah Karya Abdul Majid Tamim (1919-2000)", Jurnal Suhuf, Vol. 13, No. 1, 2020: 27-53 DOI: https//doi.org/10.22548/shf.vi3ii 533

Kamil, Ahmad Zaidamil dan Fawaidur Ramadhani, "Tafsir Alquranbahasa Madura: Kajian atas Tafsir Alqur'anul Karim Nurul Huda Karya Mudhar Tamim”, Jurnal Suhuf, Vol. 12, No. 2 (2019): 201-225 DOI:https//doi.org/10.22548/shf.visis.475

Kartini, Yulia Esti, "Fakta Sosial Bahasa Jawa dan Eksistensinya", Dinamika, Vol. 31, No. 1, (2009): 7-15.

Mar'ah, Retno Khoirul, dan Umi Hartati, "Penggunaan Bahasa Jawa Dialek Banyumas dalam Seni Begalan di Cilacap”, Caraka, Vol. 2, No. 1, (2015): 119-132.

Munawir, "Alqurandan Terjemahnya Bahasa Jawa Banyumasan (Telaah Karakteristik dan Konsistensi Terjemahan Juz 30)", ibda, Vol. 17, No. 2, 2019.

Wijana, I Dewa Putu, "Pemertahanan Dialek Banyumas Terhadap Dominasi Dialek Solo-Yogya", Humaniora, Vol. 17, No. 2, (2005): 154-159

\section{Wawancara}

Wawancara dengan Choirul Fuad Yusuf di hotel Aston Yogyakarta pada tanggal 24 Mei 2018 pukul 19.00 wib.

Wawancara dengan Ahmad Tohari, pada tanggal 27 Agustus pukul 10.00 wib.

Wawancara dengan Ahmad Muttaqin, di ruang IAIN Purwokerto pada tanggal 27 Agustus pukul 13.30 wib.

Wawancara dengan KH. Toha Alawy al-Hafidz di Ponpes At-Tohiriyah pada tanggal 1 September 2018.

\section{Website}

http://www.thohiriyyah.com/abuya-kh-m-thoha-alawy-al-hafidz/ (diakses pada tanggal

27 Agustus 2018 pukul 22.00 wib)

http://hakimsyukrie.com/quran-terjemah-basa-ngapak/ (diakses pada tanggal 19 September 2018)

https://www.dream.co.id/news/ini-alasan-Al-Qur'an-diterjemahkan-ke-bahasabanyumasan-151203u.html (diakses pada tanggal 19 September 2018).

Hakim Syukrie dalam https://hakiemsyukrie.wordpress.com/2016/05/13/quranterjemah-basa-ngapak/ (diakses pada tanggal 13 Mei 2016) 